\title{
The New Generation
}

\author{
JOAQUIM MARIA MACHADO DE ASSIS \\ translated by \\ ROBERT PATRICK NEWCOMB \\ University of California, Davis
}

\section{Translator's Preface}

"A nova geração" (The new generation), published in December 1879 in the Revista Brasileira, is among the best-known and most substantive works of literary criticism written by Joaquim Maria Machado de Assis (1839-1908). The bulk of Machado de Assis's criticism was written prior to "The New Generation," during his so-called "immature" or Romantic phase, in which the Rio de Janeiroborn writer published four well executed but not particularly original novels of manners set in Brazil's capital city. He also produced a substantial amount of poetry and short fiction during this period, describing this work at the conclusion of his essay as "neither significant nor fruitful, [but] pursued with dedication and sincerity." Machado's status as a giant of Brazilian literature rests on the socially incisive and formally innovative fiction he would publish from the $1880 \mathrm{~s}$ forward, beginning with Memórias Póstumas de Brás Cubas (The posthumous memoirs of Brás Cubas, 1881), a fictionalized romp of a memoir narrated from the grave by a mediocre but charming bachelor.

"The New Generation," then, is written at an inflection point in Machado's intellectual and literary evolution. Beyond its treatment of a heterogeneous group of mostly forgotten Brazilian poets, the essay's interest lies in its articulation of ideas that would preoccupy Machado as a mature writer. At the same time, the essay builds on themes developed in his earlier criticism, particularly "Notícia da atual literatura brasileira: Instinto de nacionalidade" (Reflections on Brazilian literature at the present moment: the national instinct, 1873) and his polemical review of Portuguese novelist Eça de Queirós's O Primo Basílio (Cousin Basílio,

\footnotetext{
1 'não fecundo nem grande mas assíduo e sincero'
} 
1878). In "The New Generation," Machado first calls on Brazilian writers to come to terms with the legacy of Romanticism, to view it not as "a simple interregnum, nor as a brilliant nightmare, nor as an effect without a cause, but as something that, though it failed to make good on all of its promises, has left behind enough to legitimize it." 2 Machado further observes: "To revile the past and to idolize it: these amount to the same vice. This is the vice of those who are ignorant of the ties that bind them to the past, and who believe that the age of human glory begins with them. This is likewise the vice of those who imagine that at some point along its path, the human spirit cast off its wings and stepped into the mire." 3

Machado's splitting of the difference between slavish imitation and fullthroated rejection of Romanticism recalls his statement from "The National Instinct" that the Brazilian writer, emerging from years of Romantic infatuation with indigenous motifs and local color, should possess above all "[a] certain intimate feeling that renders him a man of his time and country, even when he addresses topics that are remote in time or space" ("The National Instinct" 89). ${ }^{4}$ Notwithstanding his lingering Romantic affinities, namely a concern for the poetic ideal and a focus on young love and its failings, Machado acknowledges Romanticism's passing in "The New Generation," noting in picturesque terms: "The day, which belonged to Romanticism, had its hours of energy, fatigue, and death, and it cast shadows over the afternoon and blackened the night." 5

While Machado de Assis may have closed the door on Romanticism in "The New Generation," he rejected a by-then ascendant realism-naturalism as a valid replacement. He describes realism as an aesthetic concerned with "inventorying" superficial material details rather than probing deeper emotional truths - a charge that could not be brought against Romanticism, whatever the faults of its "personal lyricism, which with few exceptions, was the most draining, trivial,

\footnotetext{
2 'um simples interregno, um brilhante pesadelo, um efeito sem causa, mas alguma coisa mais que, se não deu tudo o que prometia, deixa quanto basta para legitimá-lo'

3 'Aborrecer o passado ou idolatrá-lo vem a dar no mesmo vício; vício de uns que não descobrem a filiação dos tempos, e datam de si mesmos a aurora humana, e de outros que imaginam que o espírito do homem deixou as asas no caminho e entra a pé num charco.' 4 'certo sentimento íntimo, que o torne homem do seu tempo e do seu país, ainda quando trate de assuntos remotos no tempo e no espaço'

5 'Esse dia, que foi do romantismo, teve as suas horas de arrebatamento, de cansaço e por fim de sonolência, até que sobreveio a tarde e negrejou a noite.'
} 
and unappealing music imaginable." ${ }^{6}$ Machado's qualms concerning realism's "inventorying" aesthetic ${ }^{7}$ and misplaced faith in the scientific accuracy of its observations would lead him to examine, similarly to Dostoyevsky, the unknowable depths of human psychology_as in his masterpiece of romantic jealousy Dom Casmurro (1900) and in several later short stories, including "Missa do galo" (Midnight Mass), "A causa secreta" (The secret cause) and "Pílades e Orestes" (Pilades and Orestes). Machado's objection to realismnaturalism was also marked by a concern for the "ideal," which contained an element of moral censure. This comes through in his reading of Carvalho Júnior's poem "Antropofagia," in which, he concludes, "sensuality effectively passes over into cannibalism." 8 Comparing the poem unfavorably to Álvares de Azevedo's Romantic sonnet "Pálida à luz da lâmpada sombria," with its "delicate mixture of naked forms and emotion," Machado asks: "Were a mere thirty years of evolution sufficient for emotion to be jettisoned, leaving behind only formsor let me be clear-flesh?"' At any rate, Machado clearly expresses his hostility to realism-naturalism in "The New Generation," describing it at one moment as "the very negation of the principle of art," and stating baldly: "[R]eality is fine; it is realism that is worthless." 10

Near the conclusion of "The New Generation," Machado cautions against "the sectarian spirit," which as he explains "moves necessarily from the hateful to the ridiculous." Machado's warning seems as concerned with scientific determinism as it does with the literary realism-naturalism he rejected. Indeed, in his novella $O$ Alienista (The Psychologist, 1881-1882) and in his invented philosophy of Humanitism, a pastiche of positivism and social evolutionism that appeared in Memórias Póstumas de Brás Cubas and Quincas Borba (1891), Machado lampooned the pretentions toward scientific objectivity of those who defended various late-nineteenth-century “-isms.” Machado's anti-determinism

\footnotetext{
6 'lirismo pessoal, que salvas as exceções, era a mais enervadora música possível.'

7 'sua estética é o inventário'

8 'é a sensualidade levada efetivamente à antropofagia'

9 'mistura tão delicada da nudez das formas com a unção do sentimento'; 'Trinta anos bastaram à evolução que excluiu o sentimento só para deixar as formas; que digo? para só deixar as carnes.'

10 'a negação mesma do princípio da arte'; 'a realidade é boa, o realismo é que não presta para nada.'

11 'o espírito de seita'; 'tem fatal marcha do odioso ao ridículo.'
} 
helps explain the severity of his judgment in "The New Generation" of Sílvio Romero (1851-1914), a poet, polemicist, and proponent of social evolutionism. In evaluating Romero's view of poetry, Machado states: “[T]his author's definition runs the risk of affirming a poetry that is scientific, and by deduction, didactic." 12 Machado judges that Romero "has no gift for poetic form," and he goes on to say the following: "The critic cannot deny that Mr. Romero has certain ideas that lend themselves to poetry, but an inability to translate these ideas into writing ultimately renders them as good as nonexistent." ${ }^{13}$ Romero would return the favor in his 1897 volume Machado de Assis, which earned him a reputation as one of Machado's most savage critics.

The majority of the poets Machado de Assis assesses in "The New Generation" have passed into literary obscurity; however, the essay merits our attention. A concern that Brazilian writers serenely accept the contributions of earlier generations without being constrained by them, a vociferous rejection of realism-naturalism with an attendant expression of concern for deeper emotional and psychological truths, and a deep skepticism toward scientific and pseudoscientific pretentions toward objectivity: these are recurring themes of Machado's criticism and animating features of the most memorable narratives of his "mature" period. With "The New Generation," we see these ideas articulated mere months before the serialization of Memórias Póstumas de Brás Cubas, with which Machado would begin to put them decisively into practice.

\section{Works Cited}

Alighieri, Dante. The Divine Comedy. Trans. Allen Mandelbaum. New York: Knopf, 2003. Print.

Baudelaire, Charles. The Flowers of Evil. Trans. James McGowan. Oxford: Oxford UP, 2008. Print.

Célso Júnior, Afonso. Poesias Escolhidas. Rio de Janeiro: H. Garnier, 1904. Print.

\footnotetext{
12 'há um perigo na definição deste autor, o de cair na poesia científica, e, por dedução, na poesia didática.'

13 'não possui a forma poética'; 'Que o Sr. Romero tenha algumas ideias de poeta não lho negará a crítica; mas logo que a expressão não traduz as ideias, tanto importa não as ter absolutamente.'
} 
Machado de Assis, Joaquim Maria. "A nova geração." Obra Completa. Ministério de Educação (Brazil), 2008. Web. 20 Apr. 2016.

—. "Notícia da atual literatura brasileira: Instinto de nacionalidade." Obra Completa. Ministério de Educação (Brazil), 2008. Web. 20 Apr. 2016.

-. "Reflections on Brazilian Literature at the Present Moment: The National Instinct.” Trans. Robert Patrick Newcomb. Brasil/Brazil 26. 47 (2013): 85101. Print.

Racine, Jean. The Dramatic Works of Jean Racine. A Metrical English Version. Vol. I. Trans. Robert Bruce Boswell. London: George Bell and Sons, 1908. Print.

We see before us a new generation, a youthful, lively generation, full of energy and conviction. But is this generation writing a new type of poetry, or at least attempting to create one? It would be absurd to respond in the negative; indeed, there is an effort under way - as yet incomplete, diffuse, and transitory - to create a new poetry. This effort, though not entirely of the future, is neither entirely of the past. Not all that glitters is gold in this new work, and what gold has been mined is not always of the finest quality. The force behind this work is neither constant nor consistent. But the essential thing is that the generation now coming into its own seems animated by a new spirit, and is uninterested in prolonging a day that should by now have come to its end.

This itself is significant. The day, which belonged to Romanticism, had its hours of energy, fatigue, and death, and it cast shadows over the afternoon and blackened the night. At times the new generation seems dismissive of Romanticism. One cannot expect the youngest of men to see things in their proper perspective, nor to favor reflection over enthusiasm. Were this otherwise, this generation would understand that the demise of a great literary movement does not require that one condemn formally and absolutely all that it upheld. Rather, its passing has added something to the treasure trove of the human spirit. More so than any other, this generation must see Romanticism not as an interregnum, nor as a brilliant nightmare, nor as an effect without a cause, but as something that, though it failed to make good on all of its promises, has left behind enough to legitimize it. It has died simply because it was mortal. "Theories come and go, 
but necessary truths endure." What Renan said a few months ago concerning religion and science can also be applied to poetry and art. ${ }^{14}$ Poetry is not, and cannot amount to, eternal repetition. It has been noted time and again that periods of artistic spontaneity and originality give way to those of convention and technical development, and it is for this reason that poetry, which is a virtual necessity of man, struggles to break free of its mold and fashion a replacement. Such is the destiny of the Romantic muse. But we find something more than oversight in the youth's disdain for Romanticism; we also see a degree of ingratitude. Some of these young men, though they now suckle at the breast of a new muse, were birthed by that grand woman, now deceased. And there are even those among them who smell purely of Romantic milk.

This said, the young poets' disdain merits explanation. As young men they heard the melody of a personal lyricism, which with few exceptions, was the most draining, trivial, and unappealing music imaginable. Subjective poetry had by then effectively reached the outer limits of convention, and had been reduced to a puerile game, a weaving together of the sentimental and the vulgar. The great days had definitively passed, and if from time to time a warming ray of light shone down on this benumbed, weakened poetry, it was perhaps the light of a star, but never the light of the sun. During these same years, something profound was taking place: the development of modern science, which for these young men stripped the stars from the sky, and gave them a different understanding of things, and a feeling that was not at all identical to that of the preceding generation. The naturalists, in refashioning material history, directed the youth toward the external world. These young men could no longer hear the curses intoned by the man from Hus. ${ }^{15}$ On the contrary, one of the intellectual traits of this new generation seems to be an optimism that is not merely calm, but is at times triumphant. While our young men certainly feel a desire to bring things down to Earth, whether institutions, beliefs, customs, or abuses, they view the universe's overarching order as perfection itself. The humanity they celebrate in their verses is far removed from Vigny's monde avorté. ${ }^{16}$ It is more sublime, it is

\footnotetext{
${ }^{14}$ Ernest Renan (1823-1892): French philosopher and historian.

15 Jan Hus (1370-1415): Czech religious leader and reformer.

16 'aborted world'; Alfred-Victor, Count of Vigny (1797-1863): French Romantic writer.
} 
a god, as the foreign poet Mr. Teixeira Bastos describes. ${ }^{17}$ Justice, whose arrival is heralded in enthusiastic verses, becomes a supplement more than a complement. And just as the theory of natural selection rewards the ablest, another law, which we could describe as the law of social selection, hands the palm of victory to the purest. This is the inverse of the biblical tradition; paradise is now found at the end of history. From time to time one hears an afflicted or melancholy note, a pessimistic note, as in Hartmann. ${ }^{18}$ But this is rare, and is becoming rarer all the time. The general feeling inclines toward apotheosis, and this is not only natural, but necessary. Life must amount to something more than perpetual despair, and the youth will be well served by a bit of pride.

What then, is the theory behind this new poetry, and what is its ideal? This question becomes all the more relevant when one considers that the new generation is seeking to define and name itself. Here, however, opinions vary, differences are noted, and contradiction and imprecision prevail. This generation possesses nothing like the introduction to Cromwell. ${ }^{19}$ For example, a far from incompetent writer, referring to a poem by Mr. Fontoura Xavier (the preface to $O$ Régio Saltimbanco [The royal acrobat]), ${ }^{20}$ affirms that this poet "possesses the defining characteristics of the new school, namely a logical fusion of realism and Romanticism, for he marries Baudelaire's faithful observations with the surprising conclusions of the old master Victor Hugo." ${ }^{21}$ Here we have a sufficiently affirmative and clear definition that, if not entirely correct, is nonetheless admirably fair-minded. I say that it is not entirely correct because Baudelaire $^{22}$ and realism are not as synonymous as the writer believes. Baudelaire vehemently rejected the title of realist, which in a note he described

\footnotetext{
${ }^{17}$ Francisco José Teixeira Bastos (1857-1902): Portuguese poet, journalist, essayist, and positivist.

${ }^{18}$ Karl Robert Eduard von Hartmann (1842-1906): German philosopher, author of Philosophy of the Unconscious.

${ }^{19}$ English poet and critic Matthew Arnold (1822-1888) won the Newdigate Prize at Oxford in 1843 for his poem Cromwell.

${ }^{20}$ Antônio Vicente da Fontoura Xavier (1856-1922): Brazilian poet, diplomat, and republican, author of the anti-monarchical satire O Régio Saltimbanco (1877).

21 'tem as caracterizações acentuadas da nova escola, lógica fusão do realismo e do romanticismo, porque reúne a fiel observação de Baudelaire e as surpreendentes deduções do velho mestre Vítor Hugo.'

${ }^{22}$ Charles Baudelaire (1821-1867): French poet, author of Les Fleurs du mal (1857).
} 
as cette grossière épithète. ${ }^{23}$ The author perhaps did not mean to imply that Baudelaire was a realist, but as we shall see presently, his definition is excellent nonetheless.

There are those who view poetic and political ideals as of a piece, and fashion these into a single idea, such that the new muse would be obliged to sing the praises of the Republic. ${ }^{24}$ This formula, with its implied body of literary doctrine, ultimately does not stand. In this poetry some traces of theories and philosophical preoccupations may be found, but nothing that is clearly expressed. One of these poets, Mr. Mariano de Oliveira, though he believes us to be in Comte's third stage, ${ }^{25}$ nonetheless affirms that a book of verses is not a philosophical compendium nor a form of propaganda, but merely a book of verses. This seems to be the general view. Another poet, whom I believe to be the newest member of the group, paints for us (Cantos e Lutas, p. 12) an appealing picture: joyful singing fills the schools and the workshops; genius vanquishes evil; God guides our conscience; the heart is kissed by goodness; liberty is achieved. This is the new idea, but what, a critic has asked, is this? (Economista Brasileiro, October 11, 1879). He protests against this notion, and finds Oliveira's description inexact. This is not the new idea. The new idea, the critic asserts, is found ten pages later, and he cites verses in which the poet clamors for shields to be smashed, spears to be broken, cannons to be made into statues and temples made into schools, and for the voice of the law to replace the sound of machine gun fire. He concludes with a vision of universal prosperity: "When Justice's holy blessing / Is given to Humanity." ${ }^{26}$ As we see, the difference is purely chronological or syntactical. What is presented here as an accomplished fact seems earlier to have been a mere premonition. This is a case of indicative versus imperative. This basic difference, which has nothing to do with the poetic ideal,

\footnotetext{
23 'that coarse epithet'

${ }^{24}$ Brazil was a constitutional monarchy between 1822 and 1889. Machado appears to reference the notion that the Republic, ascendant since the American and French revolutions, represented the future.

${ }^{25}$ Antônio Mariano Alberto de Oliveira (1857-1937): pharmacist, educator and poet. The "third stage" refers to French philosopher August Comte's theory of humanity's historical development by stages, which concludes with the third, "positive" stage. Machado wrote an introduction to Oliveira's Meridionais (1884).

26 'Quando pairar por sobre a Humanidade / A bênção sacrossanta da Justiça'
} 
divides the author from the critic. Justice, hailed by Mr. V. Magalhães, ${ }^{27}$ is found in other writers - for example, in Mr. Teófilo Dias (Cantos Tropicais, p. 139). ${ }^{28}$ This idea is common to our modern poets and to those of Portugal. The leader of these Portuguese poets, Mr. Guerra Junqueiro, takes this as his poetic motto: "As straight as justice," as he writes in one of his lovely verses from A Musa em Férias. ${ }^{29}$ Mr. Guilherme de Azevedo, one of his closest comrades, wrote in a letter that opens the book A Alma Nova: "Both in moments of good humor and struggle, [this book] speaks of humanity and Justice." ${ }^{30}$ Another poet, Mr. Teixeira Bastos, states in Rumores Vulcânicos that his verses sing of a holy godHumanity - and of "Justice's brilliant image." ${ }^{31}$ But this aspiration toward the kingdom of Justice (which is borrowed whole cloth from Proudhon) ${ }^{32}$ does not a literary doctrine make. It is an aspiration and nothing more. It might also amount to a crusade, and I am not averse to poetic crusades. Garrett, ${ }^{33}$ who like the great poet he was could at times be naïve, erroneously attributes a number of great social achievements to our poor poetic muse. But let these young men come along and sing of something new - justice, for example, so that God willing they might one day disprove Pascal! ${ }^{34}$ Nonetheless, there remains a difference between a

${ }^{27}$ Presumably the author of the October 11, 1879 article in the Economista Brasileiro.

${ }^{28}$ Teófilo Dias de Mesquita (1854-1889): nephew of Romantic poet Gonçalves Dias and author of Cantos Tropicais (Tropical Songs, 1878).

${ }^{29}$ Abílio Manuel Guerra Junqueiro (1850-1923): Portuguese poet. Machado quotes from the fourth verse of "A musa," the first poem of A Musa em Férias (1879). The poem begins as follows: "Das suas tranças douradas / Nem uma só é postiça; / É casta como as espadas, / É recta como a justiça" 'Of her golden locks / Not one is false; / She is chaste as a sword / She is as straight as justice.'

30 'Sorrindo ou combatendo fala [o livro] da humanidade e da Justiça.' Guilherme de Azevedo (1839-1882): Portuguese poet. A Alma Nova was published in 1874.

31 'coruscante vulto da Justiça.' Teixeira Bastos (1857-1902): Portuguese poet. His Rumores Vulcânicos was published in 1878. Machado quotes from the poem "Estes versos," whose third stanza contains the following verses: "Cantam um Deus sagrado, / Um Deus grande e potente - a Humanidade, / E o coruscante vulto da Justiça!" 'They sing of a holy God, / A great and powerful God - Humanity, / And of Justice's brilliant image!'

${ }^{32}$ Pierre-Joseph Proudhon (1809-1865): French anarcho-socialist and federalist.

33 João Baptista da Silva Leitão de Almeida Garrett (1799-1854): Portuguese Romantic writer and liberal politician.

${ }^{34}$ French thinker Blaise Pascal (1623-1662), author of the Pensées (posthumously published, 1670). 
social aspiration and an aesthetic idea. What is called for is an aesthetic definition.

Might we find our definition in Mr. Sílvio Romero's preface to his Cantos do Fim do Século? ${ }^{35} \mathrm{He}$ states: "Those who aspire to give art a new direction cannot agree. Some rally to revolution, others to positivism. Socialism and the new form of Romanticism also have their defenders. These doctrines, like metaphysical idealism, are prone to exaggeration. None represents the truth." 36 Not content to merely observe these differences of opinion, Mr. Sílvio Romero examines the various positions one by one, and quickly demolishes each of them. None can satisfy the aspirations of the present moment. Revolution lacked intellectual heft. Positivism as a system is finished. ${ }^{37}$ Socialism lacks positivism's high-minded philosophical commitment. The "new form of Romanticism" amounts to an empty formula. And metaphysical idealism is nothing more than a hysteric's dream. All of this is expressed in three pages. It bears noting that this author, unlike the others, eloquently defends lyricism, which is generally confused with "Romantic melancholy." He expresses this point perfectly, and I wholly accept it. This said, lyricism cannot satisfy the needs of poetry today, or as the author states, "it is not wholly adequate to this literary environment, for there exists a new understanding [of literature, or poetry specifically] that is broader and firmer." ${ }^{38}$ But what new understanding is this? This is the controversial point, and after refuting all of the prevailing theories, Mr. Sílvio Romero concludes that the new understanding of literature that he defends is not at all dogmatic. Rather, it is the product of the broadly critical spirit of the present age. This definition, which has the disadvantage of not being an aesthetic one, nonetheless conveys an idea that is reasonable, and is also broad, flexible, and adaptable to this age, in which the spirit pulls back from its

${ }^{35}$ Sílvio Romero (1851-1914): folklorist, poet, proponent of social Darwinism and critic of Machado de Assis. His Cantos do Fim do Século were published in 1878.

36 'Os que têm procurado dar nova direção à arte não se acham de acordo. A bandeira de uns é a revolução, de outros o positivismo; o socialismo e o romantismo transformado têm também os seus adeptos. São doutrinas que se exageram, ao lado da metafísica idealista. Nada disto é verdade.'

${ }^{37}$ The phrase "o positivismo está acabado como sistema," could also be taken to mean that Positivism is a complete, self-enclosed, and therefore "finished" (acabado) system.

38 'não pode por si só encher todo o ambiente literário; há mister uma nova intuição mais vasta e mais segura.' 
surroundings. But it is not enough that poetry be considered the broad result of the criticism of the age. And without passing over into dogmatism, Mr. Sílvio Romero should have affirmed something more. To state that poetry should be the product of its time is to affirm nothing more than a commonplace of all artistic phenomena. What is more, this author's definition runs the risk of affirming a poetry that is scientific, and by deduction, didactic - a type of poetry that, incidentally, has been with us since Lucretius. ${ }^{39}$

I nearly failed to mention a position some defend - realism - which is the weakest of all, for it is the very negation of the principle of art. I should note that Mr. Sílvio Romero defends realism, less as the doctrine that it is than as the expression of a certain violent note that is present, for example, in the sonnets of Mr. Carvalho Júnior. ${ }^{40}$ This said, of all of the positions that might attract our young men, realism seems the least likely to endure, and for good reason: there is nothing about it that can sustain the interest of those with a poetic vocation. On this point all of the schools are in agreement, and Racine's feelings would be identical to those of Sophocles. ${ }^{41}$ The poet V. Hugo has stated that there is an insuperable barrier between reality in art, and reality in nature. ${ }^{42}$ The critic Taine has written that if the faithful copying of reality were the object of art, then the best possible novel or drama would be an exact reproduction of a legal proceeding. ${ }^{43}$ This principle is neither classical nor Romantic, and is of a higher order than the struggles and particular theories that have announced themselves down through the ages.

From all that has been said it should be apparent that today's youth feel differently than the first and second generations of Romantics, though the current poetic movement has not yet achieved its characteristic, definitive form. This observation should not be interpreted as a slight against our young men. They cannot create and shape this movement on their own, but will necessarily absorb outside influences, as occurred with the preceding generations. The Generation

${ }^{39}$ Titus Lucretius Carus: Roman poet and author of De rerum natura (On the nature of things).

${ }^{40}$ Francisco Antônio de Carvalho Júnior (1855-1879): Parnassian poet, author of Parisina (1879).

${ }^{41}$ Jean Racine (d. 1699): French classical dramatist; Sophocles (c. 496-406 BCE), ancient Greek dramatist.

${ }^{42}$ Victor Hugo (1802-1885): French Romantic poet, dramatist, and novelist.

${ }^{43}$ Hippolyte Taine (1828-1893): French critic and historian. 
of $1840,{ }^{44}$ for example, inherited everything from the European movement of $1830,{ }^{45}$ with this exception: their attempt to create a truly American poetry identified with our Indians. ${ }^{46}$ This project is praiseworthy, if judged solely by its literary results, but is more questionable and even groundless if judged by the literary school it effectively created. The new generation, whatever its talents, cannot escape the environmental conditions that shape it. The current movement may affirm itself through personal inspiration, or the particulars of its literary output, but external influences are what give it direction. It seems a truism that our land does not yet possess the energy necessary for the invention of new doctrines. ${ }^{47}$

And here I touch upon a truly objectionable feature of the definition provided by the author of the preface to Mr. Fontoura Xavier's book. ${ }^{48}$ It is true that V. Hugo and Baudelaire have quite directly influenced some of our young poets. There is a movement, located principally in the North and begun in Pernambuco, that is imitative of V. Hugo. Some call this the Hugoist school, or the condoreira school, as I read some weeks ago in a bibliographic article written by $\mathrm{Mr}$. Capistrano de Abreu, one of our modern talents. ${ }^{49}$ This movement has given rise to the verses of Castro Alves, ${ }^{50}$ Tobias Barreto, ${ }^{51}$ Castro Rebelo Júnior, ${ }^{52}$ Vitoriano Palhares ${ }^{53}$ and other men of greater or lesser talent. However, I believe that the movement ended with the author of "Vozes d'África." The poetry of Mr. Castro Alves is distinguished by a sometimes excessive pomp, along with a

${ }^{44}$ Here Machado refers to Brazil's second Romantic generation, which included Álvares de Azevedo, Junqueira Freire, and Fagundes Varela.

${ }^{45}$ Machado appears to refer to a later phase of European Romanticism, and possibly to France's July Revolution, which in July 1830 saw Charles X overthrown and a constitutional monarchy under Louis-Philippe established.

${ }^{46}$ Machado uses the adjective indiática to describe this poetry, which is commonly identified with the Brazilian literary movement indianismo.

${ }^{47}$ In the Portuguese: "Creio que isto chega a ser uma verdade de La Palisse." Machado appears to invoke the French term lapalissade, that is, a comic or obvious truism.

48 José Lopes da Silva Trovão (1848-1925): journalist and republican.

49 João Capistrano de Abreu (1853-1927): historian of colonial Brazil.

${ }^{50}$ Antônio de Castro Alves (1847-1871): Romantic poet of both lyrical and socially engaged inclinations. Best known for the anti-slavery poems "O navio negreiro" and "Vozes d'África."

${ }^{51}$ Tobias Barreto de Meneses (1839-1889): poet and journalist, from Sergipe.

52 João Baptista de Castro Rebelo Júnior (1853-1912): poet and intellectual, from Bahia.

${ }^{53}$ Vitoriano José Mariano Palhares (1840-1890): poet, from Recife. 
certain swelling of ideas and phrases, and an ostentatious use of metaphor. These things, if applied to an entire school, could not be seen as virtues. For this very reason the movement ended with him. Now then, V. Hugo is imitated more for his conceptualism than for his explosive form. His axiomatic tendency, his use of antithesis, his lively and refined images, the Olympian air of his adjectives, and finally his metrical choices are frequently imitated, and not without positive results. Mr. Guerra Junqueiro and his disciples in the modern Portuguese school of poetry have contributed significantly toward this imitation. As for Baudelaire, I would say that the imitation of this poet is more intentional than successful. The tone of Baudelaire's imitators is excessively crude, and in fact, this crude imitation is the only Baudelairean tradition that we have. It is misguided. Enough of Satanism! The author of Don Juan aux enfers is more of a realist than the author of Tristesses de la lune $!^{54}$ Now then, doesn't this reproduction-which is often reproduction and nothing more - this assimilation of the feelings and way of being of two highly original talents - limit the talent of the imitating poet? Isn't it an obstacle to the poet's greater development? Doesn't it expose him to the danger of reproducing mannerisms instead of spirit, of reproducing the face as opposed to the whole person? What is more: doesn't it also carry with it the temptation to only reproduce the great poet's defects, and in reproducing them, exaggerate them, as is the tendency of all intransigent disciples?

France's influence is also apparent in poetic meter, in the decline or wholesale rejection of free verse, and in the frequent or even exclusive use of the Alexandrine. This meter is truly excellent, and to employ a musical simile, while it is not as melodious as other meters that are more genuinely ours, it is seldom surpassed for harmony. Its use is not recent in our language, even among us Brazilians. Beginning with Bocage, ${ }^{55}$ poets have attempted to adapt it to our climes. Castilho made quite accomplished use of it. ${ }^{56}$ The criticism of the Alexandrine as being foreign in origin is weak and lacks merit. Literary forms, like literary theories, become tired and require renewal. Isn't this precisely what the Romantics of 1830 and 1840 did when they sought out and rejuvenated certain archaic poetic forms?

\footnotetext{
${ }^{54}$ Both of these poems appear in Baudelaire's Les Fleurs du mal.

${ }_{55}^{55}$ Manuel Maria Barbosa du Bocage (1765-1805): Portuguese Neoclassical poet.

${ }^{56}$ António Feliciano de Castilho (1800-1875): Portuguese Romantic poet.
} 
As for the decline of free verse, this is a fact, and a fact of great importance for the poets of our language. Free verse, which we have employed for so long, and which was put to such vigorous use by Junqueira Freire ${ }^{57}$ and Gonçalves Dias,${ }^{58}$ is evidently in decline. There is no denying it. The moment when Filinto energetically declared his love of free or blank verse, a love rooted in Latin and Neoclassical poetry, is long past. ${ }^{59}$ It has been said that free verse was made for the eyes only. Blank verse seems to be verse only to the eye. ${ }^{60}$ Johnson, ${ }^{61}$ who cites this statement in order to condemn Milton's preference for free verse, observes that not one of the Italian poets he cites, who banned rhyme from their poetry, is considered popular. ${ }^{62} \mathrm{I}$ would apply this observation to our own writers. Though I do not question the merit of our great lyric poet Gonzaga, ${ }^{63}$ it seems evident that José Basílio da Gama was an even greater poet. ${ }^{64}$ Gonzaga had poetic grace, sensibility, and a command of melody and style. Indeed, he managed to transplant the shepherdesses and their academic sheep from the Tagus to Minas Gerais. Basílio da Gama's best work is quite distinct from Gonzaga. Basílio da Gama, like Gonzaga, lacked neither sensibility nor style. He had both in spades. His imagination is far superior to Gonzaga. And as for his versification, no other poet is as harmonious and pure as Basílio da Gama. If Johnson had been able to read him, he no doubt would have emended the idea of

\footnotetext{
${ }^{57}$ Luís José Junqueira Freire (1832-1855): Benedictine monk and poet. His work bridges Neoclassicism and Romanticism.

${ }^{58}$ Antônio Gonçalves Dias (1823-1864): One of Brazil's most important Romantic poets, notable for his lyricism and celebrations of Brazilian nature and indigenous life and traditions.

${ }^{59}$ Francisco Manuel do Nascimento (1734-1819): Portuguese Neoclassical poet, wrote as "Filinto Elísio."

${ }^{60}$ This statement, transcribed in English and in italics in Machado's original, is attributed by Samuel Johnson to an "ingenious critic," and is taken from Johnson's treatment of John Milton in his Lives of the Poets (1779-81).

${ }^{61}$ Samuel Johnson (1709-1784): giant of eighteenth century English letters, biographer, poet, critic, essayist, and lexicographer.

${ }^{62}$ John Milton (1608-1674): English writer best known for his epic poem, Paradise Lost (1667).

${ }^{63}$ Tomás Antônio Gonzaga (1744-1810): Luso-Brazilian Neoclassical poet, best known for Marilia de Dirceu (1792-1812) and the satirical, anonymous Cartas Chilenas.

${ }^{64}$ José Basílio da Gama (1740-1795): Luso-Brazilian Neoclassical poet, author of the epic O Uraguai (1769).
} 
his ingenious critic. ${ }^{65}$ These merits notwithstanding, Basílio da Gama is a much less popular poet than Gonzaga. Or put another way, Basílio da Gama is not universally considered a popular poet. No one, from those who take the greatest pride in being men of letters to those who could not be less concerned with poetry, no one has failed to read the Inconfidente's book at least once. ${ }^{66}$ Many of his poems can be recited from memory. Basílio da Gama's reputation, in contrast, is almost entirely literary. The principal reason for this disparity is certainly of greater magnitude than the poet's choice of meter, though the English critic's observation is nonetheless well taken. Is it not also true that Gonçalves Diass' rhymed verses have put down firmer roots than his unrhymed verses, and that more readers are familiar with his "Canção do exílio" and "Gigante de pedra" than have read the four cantos of Os Timbiras?

All this being said, it is now time to analyze the new poets. We have seen that there is a new tendency in poetry, the product of the tedium caused by the abuse of subjectivism, and of modern scientific theories. We have also seen that this tendency is not yet entirely fixed, and that its writers are attempting to give it definition and a credo. Finally, we have seen that this movement is strongly influenced by foreign literatures. Now let us turn to the new poets, as a group and individually. I will not address every last one of them, but only a certain number, for I cannot include them all. Those I will include are those whose talent, and the sort of talent they possess, is sufficient to give us an idea of the elements that define the current generation. Let us read them affectionately, serenely, and with that discipline of spirit that we should model for our young men.

II

The new poets are not a coherent group. Some remain faithful to the traditions of late Romanticism - though theirs is a partial and somewhat rebellious faith, as we see in Mr. Lúcio de Mendonça ${ }^{67}$ for example, and in some pages of Mr. Teófilo Dias's Cantos Tropicais. Mr. Afonso Celso Júnior, who wrote his first

\footnotetext{
${ }^{65}$ Transcribed in English and in italics in Machado's original.

${ }^{66}$ Here Machado references Gonzaga's participation in the failed Inconfidencia mineira revolt, and presumably refers to Gonzaga's Marilia de Dirceu.

${ }^{67}$ Lúcio de Mendonça (1854-1909): lawyer, journalist, short story writer, and poet. A cofounder, with Machado de Assis and others, of the Academia Brasileira de Letras.
} 
compositions in the language of Romanticism, today speaks in another tongue. There is a notable difference between his Devaneios and his Telas Sonantes, as indicated by their titles. ${ }^{68}$ Not all poets of this generation have undertaken a similar transformation, or at least I do not have the documentation that would indicate as much. Every so often one encounters the odd vestige of Castro Alves. All of this, as I have explained, is indicative of a process of transition, inconsistently expressed, and running from the most recent poems of Mr. Teófilo Dias through the sonnets of Mr. Carvalho Júnior.

Let us dedicate a few moments to the latter poet, now deceased. He left behind just a few poems, some twenty sonnets, which his dedicated and talented friend Mr. Artur Barreiros collected along with some other writings and published as a volume, as a posthumous tribute. Mr. Carvalho Júnior was the precise opposite of Mr. Teófilo Dias. He exemplified a sensual form of poetry that somewhat carelessly has been called, and is still called, realism. The violent and so purely carnal aspect of his poetry appears in the work of no other poet from our country. He does not attempt to hide this, but declares it in the first lines of his collection: "I hate pale, anemic virgins, / Beauties taken from a missal." And in the sonnet's conclusion: "I prefer the exuberance of shapes, / The beauty of form, and its adornments, / Health, flesh, life." 69

Here we have the poet, presenting himself wholly and frankly. He does not find pale virgins merely disagreeable. Disagreeableness is an emotion for the weak. Rather, he hates them, for hate is the emotion of the strong. Here he presents us with his credo and does not hold anything back. He calls things by their proper name, "flesh" if flesh is needed. Is there sincere feeling behind all of this, or does the poet make these choices purely for literary effect? Mr. Artur Barreiros leans toward the second possibility. He states: "There must be some

\footnotetext{
${ }^{68}$ Afonso Celso de Assis Figueiredo Júnior (1860-1938): poet, Imperial-era politician, and magistrate from Minas Gerais. Perhaps best known for the nationalistic text Por Que me Ufano de Meu Pais (1900), which popularized in Brazil the term ufanismo, that is, an exaggerated and uncritical nationalism. His collection Devaneios was published in 1877 , and Telas Sonantes in 1879.

69 'Odeio as virgens pálidas, cloróticas, / Belezas de missal'; 'Prefiro a exuberância dos contornos, / As belezas da forma, seus adornos, / A saúde, a matéria, a vida enfim.' These lines are taken from the poem "Profissão de fé."
} 
amount or degree of artificiality in this excessive love of flesh." ${ }^{\text {"70 }}$ Those who read the poem entitled Antropofagia will likely conclude that this is indeed the case. I know of no other piece of literature in our language that is written in this tone. Here sensuality effectively passes over into cannibalism. The poet's instinctive desires are those of a cannibal, and he compares them to those of rutting jennies: "Like a voracious band of rutting jennies." quite something, is not all. The images have not reached their culmination, which is found in the figure of the wild beast: "As the wild beast flares its nostrils / And sizes up its unhappy kill before taking it down / I envelop you in the brilliant light crackling / From my eyes and, shaking, I pull you to my breast." "72 Here we have bestial hunger, sensuous vermin and fevered bodies - all in the space of one page! ${ }^{73}$ Elsewhere desires are described as "vultures gathered around a carcass." 74 Attenuation of form and subtlety of style were unknown to Mr. Carvalho Júnior. Half tones held no interest for him. Of all of the colors of the palette what truly attracted him was scarlet. In the twenty sonnets that he produced, he seldom failed to commemorate an erotic conquest, scene, or memory. And I understand the faithfulness of Mr. A. Barreiros who, in attempting to collect his friend's few compositions, did not wish to exclude anything that might contribute to the study of the literary spirit of our age. It was nearly thirty years ago that Álvares de Azevedo gave us in his sonnet "Pálida à luz da lâmpada sombria" such a delicate mixture of naked forms and emotion. ${ }^{75}$ Were a mere thirty years of evolution sufficient for emotion to be jettisoned, leaving behind only forms - or let me be clear-flesh? To speak of "forms" implies a certain concern for the ideal, which Mr. Carvalho Júnior utterly banished from his poetry. And yet this young man was a poet, and a born poet.

\footnotetext{
70 'Neste descompassado amor à carne certo deve de haver o seu tanto ou quanto de artificial.'

71 'Como um bando voraz de lúbricas jumentas'

72 'Como a besta feroz a dilatar as ventas / Mede a presa infeliz por dar-lhe o bote a jeito

/ De meu fúlgido olhar às chispas odientas / Envolvo-te, e, convulso, ao seio meu t'estreito.'

${ }^{73}$ Machado references the phrases "fomes bestiais," "vermes sensuais," and "carnes febris," all taken from the second tercet of the sonnet "Antropofagia."

74 'urubus em torno da carniça.' This phrase is taken from the poem "Adormecida."

${ }^{75}$ Manuel Antônio Álvares de Azevedo (1831-1852): Ultra-Romantic poet, short story writer, and essayist.
} 
The pictures he painted were excessively crude, but his pen was uncommonly vigorous, and he had an uncommon talent for poetic description. Mr. A. Barreiros describes his sonnets and poems as written in the manner of Baudelaire, but as also marked by our poet's individual temperament. To appreciate the accuracy of Mr. Barreiros's observation, one need only compare Mr. Carvalho Júnior's "Profissão de fé" to any number of moments from the Flowers of Evil. ${ }^{76} \mathrm{Without}$ a doubt Baudelaire inspired our poet. Where Mr. Carvalho Júnior speaks of "belezas de missal," Baudelaire writes of "beautés de vignettes." If Baudelaire does not speak of "virgens cloróticas," it is because he expresses this idea another way, leaving these virgins to Gavarni, "poète des chloroses." difference in temperament between the poets reveals itself in the fact that while ours hates virgins, the other is content to say that they cannot satisfy the heart. Though this is enough to differentiate them, their degree of difference can best be confirmed if one reads the tercets with which they close their respective poems. As we have seen, Mr. Carvalho Júnior prefers the exuberance of shapes, health, and flesh. But consider Baudelaire: “Ce qu'il faut à ce cœur profond comme un abîme, / C'est vous, Lady Macbeth, âme puissante au crime, / Rêve d'Eschyle éclos au climat des autans; // Ou bien toi, grande Nuit, fille de MichelAnge, / Qui tors paisiblement dans un pose étrange / Tes appas façonnés aux bouches des Titans!"’78

Mr. Carvalho Júnior, giving in to his personality and to recklessness, makes a purely carnal profession of faith: he cannot follow the example of his model, who is considered a realist, and who confesses a rouge idéal and who finds Lady Macbeth, who satisfies his heart, profond comme un abîme. ${ }^{79}$ Here we find ourselves at some distance from the boudoir. This said, it is apparent that Baudelaire fascinated Mr. Carvalho Júnior, and that he inspired some of his compositions. And it is apparent that he followed Baudelaire's example in his

\footnotetext{
${ }^{76}$ Translated by Machado as Flores do Mal.

77 'beauties of vignettes'; 'That poet of chorlosis, Gavarni'. These phrases are taken from Baudelaire's poem "L'Idéal" as are the closing tercets quoted at the end of this paragraph. Paul Gavarni (1804-1866, born Hippolyte-Guillaume-Sulpice Chevalier), was a French lithographer and painter.

78 'I need a heart abyssal in its depth, / A soul confirmed in crime, Lady Macbeth, / Aeschlyus' dream, storm-born out of the south, // Or you, great Night of Michelangelo's, / Who calmly twist in an exotic pose / Those charms he fashioned for a Titan's mouth.'

${ }^{79} \mathrm{Lady}$ is transcribed in italics in Machado's original.
} 
lively descriptions, and in the musicality of his words. But Mr. Carvalho Júnior's individuality shines through in his book, and comes to entirely dominate his poetry. He was a poet. His poetry was always violent, and was sometimes repulsive, priapic, and unappealing. But in the end he was a poet. These lines from the poem "Nêmesis" are hardly the work of an amateur: "There is, in your translucent and magnetic gaze / The magical attraction of a precipice, / And in your nervous, skeptical laugh, / The silvery vibrations of vice. // In your walk, in your morbid, splenetic gestures, / There is something noble and patrician, / And a metallic, frenetic sound, / Like the clanging of chains in a scene of torture." 80

Would you like to see the opposite of Mr. Carvalho Júnior? Then read the work of Mr. Teófilo Dias. His Cantos Tropicais were published one year ago, and are his most recent work. His debut volume, Lira dos Verdes Anos, revealed Mr. Téofilo Dias's qualities, but not fully, because it was only later that a new tendency began to shine through, albeit vaguely, from his work. The author of the Cantos Tropicais is Gonçalves Dias's nephew, a fact that is not only of biographical interest, but of literary interest as well. Mr. Teófilo Dias's sense of poetry and the sweetness and refinement of his verses often recall the bard of $O s$ Timbiras, without sacrificing any of his originality. We might say that this is a case of family resemblance. Reading the work of both men, one perceives what separates them. Gonçalves Dias had energy in spades, and at times displayed a tumultuous emotional life - neither of these is characteristic of his nephew's poetry. Mr. Teófilo Dias's principal tone is a melancholy tenderness. When necessary, he can add a virile note to his poetry, as in "Batismo do fogo," "Cântico dos bardos," and two or three other compositions. But one senses that in these moments, the poet intentionally summons a certain degree of virility. One senses that he could go further if necessary, but this virility is not the dominant cord of his poetic lyre. On the other hand, there are certain audacious elements in Mr. Teófilo Dias's style that are not found in the author of "I-JucaPirama," and that might be called the mark of our time. I would cite, for example, the opening verses of a sonnet, which is one of the finest of the Cantos Tropicais:

\footnotetext{
80 'Há nesse olhar translúcido e magnético / A mágica atração de um precipício, / Bem como no teu rir nervoso, céptico, / As argentinas vibrações do vício. // No andar, no gesto mórbido, splenético, / Tens não sei que de nobre e de patrício, / E um som de voz metálico, frenético, / Como o tinir dos ferros de um suplício.'
} 
"In the light radiated by your melancholy gaze, / There are spiritual sounds/." These "spiritual sounds," that "melancholy gaze," and that "gaze that radiates" are more the products of this generation than of its predecessor. And if some of my readers - that is, my older readers - raise their eyebrows, as the defenders of the old Parnassus did at the moonlight of the upstart Musset, ${ }^{82}$ then I will certainly refrain from reciting to them this verse from a modern-day compatriot of Racine: Quelque chose comme une odeur que serait blonde, ${ }^{83}$ because they may look upon it with suspicion. Instead, I'll turn to this old chestnut from PortoAlegre: "A melodious flame spills into the air." 84

If Lira dos Verdes Anos did not fully reveal Mr. Teófilo Dias, it nonetheless showcased some of his qualities, and it is a valuable proof of his talent. Several of the poems from this volume- "Cismas à beira-mar," for example-could plausibly appear in his second collection. While it is perhaps true that this composition's style is a bit conventional, it also displays poetic feeling and in certain moments, very skillful expression. The Cantos Tropicais have made good on the promise of Lira dos Verdes Anos. Mr. Teófilo Dias's progress is evident, and as I have said, there is something new here in the poet's spirit. This said, the contrast is not so great as to support the poet's assertion from his first book that when he wrote those poems he thought differently than he did by the time they were published. I believe that his statement is truthful, but one cannot deduce this from his work. In the Cantos Tropicais the poet refines his talents, works to vary his tone, and looks near and far for inspiration. But the dominant chord of his poetry carries over from his debut collection.

There are poets whose sadness is like a wallflower they pluck and wear as an adornment. One feels that Mr. Teófilo Dias's verses, when they are sad, reflect

\footnotetext{
81 'Na luz que o teu olhar azul transpira, / Há sons espirituais;' These verses are taken from Teófilo Dias' "Olhos azuis." The phrase "olhar azul" suggests both the idea of melancholy and the blue color of the titular woman's eyes.

${ }^{82}$ Alfred de Musset (1810-1857): French playwright and poet, author of the poem "Ballade à la Lune."

83 'something like a blonde scent.' This is the final verse from François Coppée's "Septembre au ciel léger taché de cerfs-volants". Coppée (1842-1903) was a French poet, playwright, and short-story writer.

84 'E derrama no ar canoro lume.' Manuel de Araújo Porto-Alegre (1806-1879):

Romantic writer, painter, and critic. Co-founder of the publications Niterói and Guanabara.
} 
the man's feelings, and are not written merely for the purpose of ornamentation. Mr. Teófilo Dias is not a despairing man, but I suspect that he may be disenchanted. And when we do not find evidence of this in his own verses, we find it in foreign compositions that he has adapted to our language. He translated "A harpa" by Moore, ${ }^{85}$ but does it not appear that he sought out "Mortos do coração," by the same poet, because it spoke more directly to him? I find one of his choices from the Flowers of Evil even more telling. The albatross, that eagle of the seas that, caught by sailors and made to walk on the ship's deck, loses the use of his wings and is subject to ridicule, this albatross to which Baudelaire compares the poet, exposed to the mockery of the crowd and betrayed by his wings - I believe that it seduced Mr. Teófilo Dias, less from a feeling of solidarity than from one of identification. He himself is the albatross. ${ }^{86}$ The poet's work deserves neither censure nor praise. Rather, I make a critic's simple observation. Would you like proof? Read the poem entitled "Anátema," a curious tale of a poet's love, a chaste and pure love whose illusion is undone when the beloved crudely voices her feelings. This composition, which concludes with a faint suggestion of Father Vieira ("I forgive you...and I avenge myself!"), ${ }^{87}$ is a corollary of the Albatross and explains the general tone of the book. The poet becomes indignant, less for the sake of morality than of his own feelings. This is the egotism of an illusion that in these four verses sobs, shouts, and then condemns, and finally survives: “...At your feet, after you, with glee / and without pain, destroyed my illusions, / An angel clothed itself in the rags, / Of the dreams you tore apart." 88

Nothing more is needed to understand this poet, with his polite sensibility, the singularity of his young age, and the idealism he summons to lift off from the ground. This is the dominant note of his book, from "Getsemani" to "Pressentimento." It mostly shines through in "Poeira e lama," despite that poem's hints of pessimism. And if in "Andalusa" he imagines "bacchanals" and

${ }^{85}$ Thomas Moore (1779-1852): Irish poet. Moore wrote several poems with the word "Harp" in the title.

${ }^{86}$ Machado repeatedly transcribes the word albatroz in italics. The poem referred to is Baudelaire's " L'Albatros."

87 'Perdoo-vos...e vingo-me!' António Vieira (1608-1697): Portuguese Jesuit missionary, master orator, diplomat, and political advisor.

88 '...Ao pé de vós, quando em delícias / Às minhas ilusões sem dó quebráveis, / Revestiase um anjo com os andrajos, / Dos sonhos que rompíeis.' 
"lascivious pulsations," I believe that this is a nightmare, and a fleeting one, rather than a dream. ${ }^{89}$ As I have stated, there are moments in Cantos Tropicais in which the poet seems to want to cast off the clothing of his youth. These are few, and in them his poetry is more energetic, and intentionally so. His poetic delivery is full-throated and virile, as in "Poesia moderna," and his thought raises itself to the level of the topic he addresses. Here we see the justice that I spoke of in the first part of this study. Here we see the modern muse, sister of liberty, taking in her hands the spear of justice and the shield of reason. To be sure, there is something odd in a poet of emotion who evokes the muse of reason, and the poet who wrote "Solilóquio" appears out of tune with the political concerns expressed in "Poesia moderna."

I would not banish the poets from my republic; I am more tolerant than Plato. ${ }^{90}$ But there is something to the fact that Mr. Teófilo Dias's political touches seem borrowed, and perhaps reflect the influence of his circle of friends. Nonetheless, there is an effort in these verses to move away from the pure sentimentality of his earliest days as a poet. And this effort is not in vain, for there is an infinite field for poetic invention located between the poles of personal confession and the aspiration toward political change. He has inspiration, warmth, and taste. His style is certainly flexible enough to accommodate a range of topics, and to address them with the precision to which we have grown accustomed. Experience will complement his inventiveness. His melodious and pure poetic voice will learn to sing of other aspects of life. "I am twenty years old and I despise life," writes Mr. Teófilo Dias in one of the best pages from his Cantos Tropicais. ${ }^{91}$ I would respond with these words from a moralist: Aimez la vie, la vie vous aimera. ${ }^{92}$

If the poet would like an exact illustration of this, he can find it in Mr. Afonso Celso Júnior. He is the author of Devaneios and Telas Sonantes. I do not know his precise age, though I believe that he is not yet twenty years old. In 1876 his poetics, his style, and his language were still tied to an extremely personal

\footnotetext{
89 'bacanais'; 'pulsações lascivas'

${ }^{90}$ Plato (428/427-348/347 BCE): ancient Greek philosopher, called for poets to be banished from his ideal Republic.

91 'Tenho vinte anos e desprezo a vida'

92 'Love life, and life will love you in return.' Statement taken from French writer and moralist Marie de Flavigny, Countess of Agoult (1805-1876), who wrote as Daniel Stern.
} 
lyricism, accordingly structured and expressed. In a series of sonnets, in which his words flowed smoothly and with a certain elegance, and which are grouped together under the common title "Mãe," the poet spoke of his soul, "sadder than Job," 93 against the background of life's difficulties and bitter struggles. How many of you aging Romantics did not employ this same style in your youth? In this book, Devaneios, which seems to have been babbled rather than written, and which in parts is not entirely correct, a less personal element shows itself. One feels that the poet would like to escape from himself. But these steps are only tentative, as is the book itself. The poet's first definitive statement will come in Telas Sonantes.

There is something that distinguishes Mr. Afonso Celso Júnior from many of his contemporaries in the new generation: his poetry does not curse, it does not exhort, it does not use invective. His is a book of scenes, whether plain or touching, amusing or dramatic. But they are true scenes, with a certain characteristic impersonal quality. We all recall the effect produced eight years ago, when the Miniaturas of Mr. Crespo, ${ }^{94}$ a talented countryman of ours, came to us from Coimbra when we least expected it. In Mr. Crespo's scenes, which incidentally did not comprise the majority of his book, we also see that the poet had removed himself. The difference is that while Mr. Crespo's scenes were the work of a pure artist, in Mr. Afonso Celso Júnior's something else is always added. This is not the poet's presence, but rather his intention. This is more clearly understood if we compare Mr. Crespo's "A bordo" with Mr. Afonso Celso Júnior's “Esboço.” Mr. Crespo's poem is a charming and I believe perfect description of the experience of being on board a ship in a period of calm seas. We see the sailors "resting on the rolls of rigging," 95 a parrot, an English lady, the English lady's little dog, a landowner on holiday, three old men playing Ombre, and other characteristic details of this sort. The wind then picks up and the ship sails on. Mr. Afonso Celso Júnior's "Esboço" depicts the end of a theatrical performance. A moving drama has been staged. A violently upset, trembling, nervous young lady leaves the theater, gets into a coach and returns to her home. She finds her servant in the doorway, anxious and trembling because

\footnotetext{
93 'mais triste do que Jó'

${ }^{94}$ António Cândido Gonçalves Crespo (1846-1883): Brazilian-born poet credited with introducing Parnassianism to Portugal.

95 'recostados em rolos de cordame'
} 
his son is sick with fever. In order to fulfill his obligation as a servant, he has stayed in the doorway the entire night, awaiting the young lady's arrival. The poet says the following of the lady: "The lady, who before the imaginary drama on stage, / Had sobbed so, / Now held back her tears / Before this living, honorable, and lonely drama. / She let forth an icy ah! and, as if looking to the old man, / And asking him in his anguish for some advice / Said without thinking, / Indifferently, / That he could go and watch over his slumbering child; / But that first he should serve her dinner." 96

Mr. Afonso Celso Júnior's idea is conveyed in the contrast between reality and poetic invention. I have noted the difference between him and Mr. Crespo. I would now note that the author of Miniaturas has exerted some influence on the author of Devaneios. I mention Devaneios specifically, as opposed to Mr. Afonso Celso Júnior's other work, because it is in this book that the reader's careful eye can detect certain details - the scene described in the sonnet "Na fazenda," the choice of certain forms and meters - that are indebted to Mr. Crespo. But in order to appreciate how influence does not negate a poet's originality, one may read two compositions that possess nearly identical titles. These are two stories, one of a woman who is always laughing, and the other of a woman who never laughs. One perhaps gave rise to the other, but what relationship exists between them, if any such relationship exists, manifests itself only in their contrasting titles. In all other respects the poems differ from one another completely. This said, Devaneios is not as valuable as Telas Sonantes. The first volume was a promise, and not quite a book.

These are the dominant characteristics of Mr. Afonso Célso Júnior: emotion and grace. We have looked at "Esboço." "Flauta" is no less significant. Truly this is not a scene, but a poem, and a modern one. Here we find more than one moment and more than one perspective. It tells a story, and there is action. An old worker has a flute, which has helped him forget the difficulties of life and put the daughter left over from his marriage to bed. Over time, work becomes harder to find, and the household is left penniless and hungry. The worker secretly

\footnotetext{
96 'A dama, que do palco ao drama imaginário, / Havia arfado tanto, / Soube reter o pranto / Perante o drama vivo, honrado e solitário. / Soltou um ah! de gelo, e como a olhasse o velho, / Pedindo-lhe talvez no transe algum conselho, / Disse com abandono,/ De indiferença cheia, / Que podia ir velar do filho o extremo sono; / Mas que fosse primeiro à mesa pôr a ceia.'
} 
begins to pawn everything he owns, and gives the money he receives to his daughter, as if it were his wage. The flute is his only source of solace. But things get worse, and now everything has been pawned. Then one day, with nothing left, the worker leaves the house and comes back with dinner. The daughter, who has been suffering the pangs of hunger, eats the food happily and is satisfied. After dinner she asks her father to play the flute, as he always has. The father tearfully confesses that he has sold the flute to save her life. There is good, true poetry in this simple and dramatic poem. None of his other poems is as successful. While "Esboço" concerns a father's love, "Cena vulgar" commemorates a mother's sorrow. And it would be as fully realized as "Esboço" if it were shorter. The idea behind the poem is not expressed with sufficient force, and the action is too brief, to justify the poem's three pages. Moreover, the conclusion - with the hurdy-gurdy man demanding to be paid, while the sobbing mother embraces her dead daughter - would be more powerful if it were written in a more sober, simpler way, without qualifiers, such as "gross rudeness" or "insolent shouts." $"$ "The simple contrast between the man and the mother is raw enough.

I have expressed a criticism. Why not another? The poem "Joia," so sober and concise, seems to me a bit artificial. A young son stands before a jewelry display case and picks out a cameo for his mother. The mother responds with a kiss, and says that this gem is better than the other. The son understands, and responds that if she has so many gems, she should pick out a necklace. ${ }^{98}$ This is amusing! Though this is not the child who speaks, but the poet. It is unlikely that the child would have understood this expression, and even if he had understood it, it is unlikely that he would have subscribed to it. The child would have insisted on the first jewel; cet âge est sans pitie. ${ }^{99}$ Still, the poem has more than one well-

\footnotetext{
97 'rudez grosseira'; 'os insolentes brados'

${ }^{98}$ In the version of the poem I consulted, in Célso's Poesias Escolhidas (Rio de Janeiro: H. Garnier, 1904), he refers to an adereço (headdress), rather than a camafeu (cameo). Further, he writes: "De certo, disse a rir, joia melhor não ha: / Mas si tão rica, assim, e generosa está, / Sem demora, em signal de nosso regozijo, / Mais um broche, um collar e uma pulseira exijo!"

99 'This age is without pity.' A quotation from "Les deux Pigeons," one of the Fables of French poet Jean de la Fontaine (1621-1691).
} 
turned phrase, such as the mother and son who "lick with their gaze" 100 the jewels displayed in the case. The poem's language possesses a simple truthfulness. I could cite some other equally beautiful poems - for instance, "No íntimo," which is a mere ten lines in length. In it a woman feeds a dog after giving her children their dinner. This simple domestic episode is very exactly described. I could also cite "Filha da paz," a poem whose dimensions and meaning differentiate it from "No íntimo," but which is skillfully conceived and executed. I could cite others still, but this would be excessive.

It is apparent that Mr. Afonso Celso Júnior looks to external reality and finds it a rich and novel source of inspiration. He has a sense for poetry, and possesses taste and style. His language is energetic, though imperfect. His verses are fluid, though not beyond criticism. At times he allows fantasy to embellish reality more fully than is advisable in narrative poetry, as in his description of the emotions of a soldier in "Filha da paz." Though here too we find reality perceptively and truly described, as in his description of the house, with its broken stool, its worn out table, and the registro and mirror hanging from the wall. ${ }^{101} \mathrm{I}$ believe that the poet's shortcomings are the products of a youthful impatience. A maiori, ad minus. ${ }^{102}$ A true poet, such as Mr. Afonso Celso Júnior, has the obligation to become a complete poet. Whether or not he succeeds will depend upon him.

I regret that I cannot say much about Mr. Fontoura Xavier, one of the brightest talents of the new generation. With the exception of one pamphlet, this poet has no published collection to his name. His verses are scattered about in various newspapers, and the poems I've been able to collect are few. I found these in a student publication from São Paulo, published in 1877 by a group of talented young men. The publication was republican in orientation, as is $\mathrm{Mr}$. Fontoura Xavier. ${ }^{103}$

100 'lambem com o olhar' In the version of the poem I consulted, Celso refers to the "mãi e filho, / O olhar todo cubiça."

${ }^{101}$ Machado appears to reference Celso's "Na paz," in which the poet writes: "Na casa, não mudára uma feição siquer, / Tudo no mesmo estado: o tamborete manco, / A mesa carunchosa, a talha d'agua, / o banco, / Na parede um Jesus lythographado." Celso's lithograph of Jesus becomes Machado's registro.

${ }^{102}$ Machado uses the Portuguese equivalent of this phrase, "quem pode o mais pode o menos," in his essay.

${ }^{103}$ Here "republican" refers to those Brazilians who advocated for the replacement of the constitutional monarchy with a republic. 
To say that Mr. Fontoura Xavier is a republican is perhaps an understatement. I hope that he takes what I am about to say in good faith: I find that his verses are marked by a certain Jacobin spirit. The Convention may well have made room for him alongside Hebert ${ }^{104}$ and Billaut. ${ }^{105}$ His Régio Saltimbanco confirms this feeling of mine. Acrobat, clown, libertine, a Benoîton on horseback, ${ }^{106}$ a god of the trampoline: these are the epithets he uses in this composition. ${ }^{107}$ His other poems are no more moderate. If these were merely the fruits of the poet's youth, we might wait for time and maturity to do their work. If this simply amounted to an erroneous interpretation of our country and society's problems, we might wait for experience to correct judgments made in haste. But there is more to it than this. For Mr. Fontoura Xavier this is a literary question, having to do with his way of being a poet.

Notwithstanding their strength, I do not believe that Mr. Fontoura Xavier's political convictions take precedence over his literary ambitions. He calls for all crowns, whether royal or ecclesiastical, to be banished, though by implication he spares the crown reserved for the poet, which he aspires to don himself. Now then, it is precisely this crown that is at issue here. Mr. Fontoura Xavier, a talented young man whose verses are lively, strong, and spontaneous, risks obscuring his individual poetic qualities by adopting a style that serves as threadbare ornamentation for a certain sort of speech native to the Old World. Rather than abandoning his political opinions, it would be to his advantage as a poet to express these opinions differently-in a style as energetic as the one he currently utilizes, but different nonetheless. The distinguished writer who penned the preface to the Régio Saltimbanco cites the example of Juvenal ${ }^{108}$ to justify the piece's satirical tone, and the poet himself speaks of Rome. Though frankly these amount to examples of misinterpretation. Where can we find Rome, that is, an entire world in its decadence, in this nation that is so lacking in history, whose final form has yet to be determined, and which in this century enjoys so little

\footnotetext{
104 Jacques-René Hébert (1757-1794): French political journalist and spokesmen for the sans-culottes.

105 Jean-Nicolas Billaud-Varenne (1756-1819): French lawyer, pamphleteer, and radical republican.

106 Machado apparently refers to the play La famille Benoiton (1865) by Victorien Sardou (1831-1908).

107 The implied target of these epithets is Brazilian Emperor D. Pedro II (r. 1841-1889).

${ }^{108}$ Decimus Junius Juvenalis (55-60?-c. 127): ancient Roman satirical poet.
} 
influence, and whose history amounts merely to a prologue? Why reproduce these well-worn comparisons? At the same time, Mr. Fontoura Xavier demonstrates the weakness of the poetic school that, in fiery verses, would declare us as great as the Andes - that most fatuous and despicable of rhymes. ${ }^{109}$ Ni cet excès d'honneur, ni cette indignité. ${ }^{110}$

I do not call upon Mr. Fontoura Xavier to reject his political opinions. As deeply ingrained as they are, I respect them. Rather, he should not smother his individual qualities as a poet. He should exercise his imagination, elevate and refine his style, and refrain in his lovely verses from granting new life to dead metaphors, and rather leave these metaphors to those poets who have no other means to grab their readers' attention.

This is not the case of Mr. Fontoura Xavier. Of the modern poets he is among the most skillful in his use of the Alexandrine. At times I believe he sacrifices perspicuity to achieve harmony, but he is not alone in this defect, and indeed, he commits it but rarely in his verses, or at least in those verses I have been able to read.

What I have said of Mr. Fontoura Xavier may be applied in part to Mr. Valentim Magalhães, who is nonetheless a less successful poet. I believe that Cantos e Lutas, published two or three months ago, is his first book. As I have already mentioned, he finds examples of the new idea in the desert sky, in workers and students singing happily, with evil defeated, God in one's conscience, goodness in one's heart, and liberty and justice soon to be achieved. He repeats this page after page, in "Prenúncio da aurora," "No futuro," "Mais um soldado"-always the same idea, expressed in largely the same manner and using the same vocabulary. One can well imagine the tone of these compositions, and the promises they make. In one the poet promises relief for suffering souls, bread for workers, and freedom for slaves, because the kingdom of justice is at hand.

In another moment, announcing that he has taken up the sword in order to join his fellow combatants, he reports that the legions of the past are being decimated, and that dogma, privilege, despotism, and pain tremble at the sound of justice. We see that, in addition to the worker having his bread and the slave

${ }^{109}$ In the original, Machado refers to the rhyme between "grandes" and "Andes."

${ }^{110}$ Machado quotes from Act 2, Scene 3 of Jean Racine's Brittanicus (1669). In Robert Bruce Boswell's English translation (London: George Bell and Sons, 1908), this phrase reads "neither this dazzling honour, nor this insult" (278). 
winning his freedom, justice will defeat suffering itself. At the same time as the poet states that he speaks of the future and not of the past, he favorably compares the medieval hero to his modern counterpart, whom he describes as a pale young man, "terrified of the blade." 111 In this contradiction, which the poet seeks to disguise and explain away, there is a degree of the uncertainty that we find, here and there, in the work of the new generation - that is, a difficulty in dedicating oneself consciously to a single, clear feeling. This is part of the personality of this transitory group.

Mr. Valentim Magalhães's verses are seldom agitated. In fact, I believe that it would be impossible to find this quality in his work, save for the page he dedicates "to an obscure dead man." 112 Here we truly observe heartfelt emotion. His friend's death leads him to adopt a naively openhearted language, one free of artifice and the desire to achieve elegance. There are brief sketches, as in "Contraste," in which the poet describes for us a beggar amid a group of people enjoying themselves and laughing on a Sunday, in a sonnet in which a poor old woman waits until dawn for her libertine son to return home, in "Miserável," and in other poems. I prefer these sketches to "Velha história." Though the poem's subject here is perfectly convincing and real, its execution is in my opinion less successful. Mr. Valentim Magalhães should pay a bit more attention to the representation of objects and the description of emotions. At times he lacks a certain stylistic unity and equilibrium. In "Deus mendigo," for example, the description of the old man begging for alms at the doors of the Sé Cathedral is excellent. The poet says the following of the beggar's melancholy eyes: "In them there is a silent resentment, / The raging humility of disgrace / That blasphemes and begs." 113 He describes these eyes with great skill, though in the succeeding verses we find some stylistic and conceptual choices that clash with the composition as a whole and diminish its merit. Why can the poet not consistently employ the same artfulness we see in his description of blacksmiths at work, with the "blood-red light of the coals reflected in their tanned faces"? ${ }^{114}$

\footnotetext{
111 'com horror à arma branca'

112 'a um morto obscuro'

113 'Há neles o rancor silencioso, / A raivosa humildade da desgraça / Que blasfema e que esmola'

114 'luar sanguíneo dos carvões a esbater-se-lhes no rosto bronzeado'
} 
By reading the poem "Dois edifícios" one may understand the origin of the ideas that animate this book, or rather, the intellectual atmosphere that surrounds its author. It is almost noon. An old killer leans against the barred window of his cell, looking out at a school. At the sound of the bell, happy children appear, running out of the school in merry confusion. The old killer looks at them and murmurs bitterly: "I never learned to read!" Would Mr. Valentim Magalhães like me to say it? This idea, to which he has dedicated a few verses, does not ring true. It is a cliché, which the Hugoist school of poets wrote about decades ago. By now it is quite discredited. Littré ${ }^{115}$ does not believe that education is an infallible, universal panacea. Spencer ${ }^{116}$ recognizes that education goes hand-inhand with morality, but goes no further. The poet's idea is not strictly true, and is in fact entirely unconvincing. The final idea, the killer's moral epiphany, is not his own, but is leant to him by the poet. In terms of form, nowhere else in his work is the direct influence of V. Hugo so apparent. We have a series of antitheses - "light and shade," "hunger and alms," "the God of liberty and the God of evil" - and this figure, which confirms the opposition between the school and the prison: "Victor Hugo gazing upon Ignatius of Loyola." ${ }^{117} \mathrm{Mr}$. Valentim Magalhães's verses have an easy, flexible quality. Stylistically, his verses are strong at times, but what they lack is correctness, which their author will give to them in due course. I believe that he is too faithful to certain influences. It cannot be said that his Cantos e Lutas is truly a book. The ideas it presents are generally borrowed, and the poet fails to present them in a unique, new way. This criticism may be severe, but it is necessary, because Mr. Valentim Magalhães is among those poets with the greatest right and responsibility to receive such criticism.

Everyone has heard the name of Mr. Alberto de Oliveira. He gave to his book of verses a title that would have been condemned by a number of his contemporaries: Canções Românticas. Truly this is an audacious title. Now then, what remains unclear is why, in spite of his title, the poet gives us "Toilette lírica," on page 43, in which he speaks of a doomed lyricism and of troubadours. Is there some hidden irony here? No, I believe that as with certain other members

\footnotetext{
${ }^{115}$ Paul-Émile Littré (1801-1881): French linguist, lexicographer, and philosopher.

${ }^{116}$ Herbert Spencer (1820-1903): English sociologist and historian. Coined the term "survival of the fittest." His Education: Intellectual, Moral, and Physical (1861) collects essays published between 1854 and 1859 .

117 'Vítor Hugo fitando Inácio de Loiola'
} 
of his generation, Mr. Alberto de Oliveira finds himself in a period of transition. His is a personal lyricism, but he is in search of a new soul. He declares on page 93, in a sonnet dedicated to Mr. Fontoura Xavier, that he reads more than stories of lovers, listens to more than tender songs, and does more than contemplate the sky: "I too can raise myself to rapture, if, in a sainted rage, / Good crushes the prideful Vices under its feet. / I, like you, page through the legend of the giants, / And I can compose a song for them on my lyre."118 This is a moving confession, but a confession is all we have. The book contains no proof of the poet's sincerity. First of all, this is because when he wrote this he had already completed the book. But there is another, more important reason. Let Mr. Alberto de Oliveira page through the legend of the giants, but he should not dedicate a canto, a verse, or even a line to it. This is the advice that a critic would give to him. Not all poets are equally suited for the same purposes - and this is perhaps the new generation's mistake: they would like to adhere to a common, singular mold. Mr. Alberto de Oliveira's verses are neither lofty nor low. His is a gentle tone, bluish in shade, and his verses have a graceful rather than epic air. Giants require a masculine tone. The author of "Luz nova" and "Primeiro beijo" can find inspiration for his verses in any number of places.

Why should the warrior have to go fight in Palestine? Let him remain in his castle, with his daughter, not so that they might both strum an out-of-tune mandolin, but rather to read about some domestic subject together! This does not diminish the poet. Rather, it is a matter of being what one's nature requires, whether this makes one a Homer or a Moschus. ${ }^{119}$

For example, "Interior" is one of the book's loveliest compositions. A little after one o'clock in the morning, a little boy awakens, and frightened of the dark, cries out for his mother. The mother comforts him and lets him nurse at her breast. This is all there is to the poem, but it is expressed with simplicity and emotion. Now then, here we have something other than the author's own emotions, the resolution of serious problems, or the recounting of great events.

\footnotetext{
118 'Também sei me enlevar; se, em sacrossanta ira, / o Bem calca com os pés os Vícios arrogantes, / Eu, como tu, folheio a lenda dos gigantes, / E sei lhes dar também uma canção na lira.'

${ }^{119}$ Homer $\left(9^{\text {th }}-8^{\text {th }}\right.$ c. BCE): ancient Greek epic poet. The Iliad and Odyssey are attributed to him; Moschus ( $2^{\text {nd }} \mathrm{c}$. BCE): ancient Greek pastoral poet. The translator thanks Vincent Barletta for information on Moschus.
} 
Rather, we have a vast field of activity located between the great and the humble. Mr. Alberto de Oliveira is a poet, and "Ídolo," "Vaporosa," "Na alameda" and "Torturas do ideal" are the work of a poet. The ease and melody of his verses are worthy of note, though I would make one stylistic criticism. I believe that the author should take a bit more care in cultivating his style. While it does not lack for movement, it lacks a certain indispensable precision. There are elements of changeability, indecision, and obscurity in his work. To conclude my critique, I would offer that these defects stem from the fact that Mr. Alberto de Oliveira's thought is somewhat indecisive and changeable. At times he fails to formulate his ideas in a positive, logical way. Rather, they are like dreams, which fall apart and then reconstitute themselves in another form.

Though Mr. Alberto de Oliveira does not sing of the giants, he has nonetheless received this or that external influence, and every once in a while he attempts to step outside of himself. As I have said: this transformative effort, when it manifests itself in his poetry, does so, and only occasionally, at the level of style. How else can we understand the ending of "Interior," with its bony dogs that "howl mournfully, loping through the mire"? ${ }^{120}$ This description and the interior emotions described in the poem do not exist in proper proportion to one another. The howling dogs were evidently added in order to present an element of realism. The poet might just as well have written that the rain loosened a poster from a wall or that the wind buffeted a bit of scaffolding. Realism is unconcerned with necessary or even accessory relationships. Its aesthetic amounts to an inventory. Can it be said, then, that Mr. Alberto de Oliveira tends toward realism? Not at all. It comes over him momentarily, as if on the breeze, but he quickly reverts to form. In this sense, we cannot read these lines: "See the blue-an infinity, / Above this speck-the earth" without recalling that they were composed in the same manner as these from Mr. Guerra Junqueiro: 'Diogenesa snail, / In his jar-a shell,' which is incidentally also the manner of V. Hugo. ${ }^{121}$ These lines do not convince us that Mr. Alberto de Oliveira has succeeded in modifying his poetic style so as to perfectly conform to that of Mr. Guerra Junqueiro. Rather, they are vestiges of an earlier, forgotten reading of the

120 "uivam tristemente trotando o lamaçal"

121 'Ver o azul,—esse infinito, / Sobre essa migalha,_-a terra'; 'Diógenes, —essa lesma, / Na pipa,- - esse caracol' Junqueiro refers to Diogenes of Sinope (d. c. 320 BCE), an ancient Greek philosopher known to sleep in a large ceramic jar in the public square. 
Portuguese poet. The nature of Mr. Alberto de Oliveira's poetry seems to recoil from the stylistic symmetry we find in Mr. Guerra Junqueiro. He does not tend toward symmetry, nor is he inclined to consider the stature of giants. He is a domestic, delicate, fine poet. He should refine his qualities as a poet, and acquire new qualities if he can, provided these do not run counter to the nature of his talent. In short, he should affirm himself.

I am told that this poet's brother is Mr. Mariano de Oliveira, who wrote a little book of one hundred pages, Versos, which went to press in 1876. They are brothers in blood only. As poets, they are like strangers. I will speak little of Mr. Mariano de Oliveira. His book is short, and I could not manage to collect any of his later compositions, which I am told have been published in newspapers. His book is imperfect. Mr. Mariano de Oliveira does not have command of Alexandrine verse, or at least he did not when these pages were printed. This is all the more unfortunate given the spontaneous, lively quality of his poems. It would be enough to correct them — stylistically, that is - for him to be a complete poet.

Would you like evidence that there is a certain force in Mr. Mariano de Oliveira's poetry? Consider, for example, "Na tenda do operário." Passing by a worker's home, the poet sees a door open. It is nighttime: "Night, dark shadows, a large, silent, deserted place; / Within everything was black and darkness surrounded everything." 122 Thinking that some crime has taken place inside the house, he sits down by the door, waiting for the owner to return. The owner returns. The poet tells him that he has made a careless mistake, but the worker replies that no one could possibly steal from him what he does not have. The poet begs leave, walks on, and pauses some steps away, and it occurs to him that he made a needless stop, for there was a sentinel watching over the house: "The angel of destitution guarding the door." 123

In this poem, which is not unique - I could cite others, such as "Nau e o homem" and "Mãe" - in this poem one feels that there is a poet at work, but the poem's imperfections disfigure it. I do not refer to the quality of the meter; the poet is careless in general. Instead I would cite obscure passages, words that are

\footnotetext{
122 'A noite, a sombra funda, o ermo grande e mudo; / Tudo dentro era negro e negro em torno tudo'

123 'O anjo da miséria a vigiar a porta'
} 
ambiguous or used inaccurately, and even rhymes that do not truly rhyme. But this would be a detailed criticism without any interest for the reader, and with only some interest for the poet. I would rather give him this advice: recall the delightful anecdote you share on page 91, in the poem entitled "Canção." A certain Laura lived on the same square as the poet, and every day she would wait for him at her window. He, however, never dared to acknowledge her, despite the stirrings of his heart. Months went by like this. One day Laura moved away, and it was only then, when he saw her leaving, that the poet greeted her. It was too late. Poetry is like this Laura. When she comes to wait for you at the window, it would be a grave error to cast her a furtive glance, to go slowly, as if one were fleeing from her. She wants more than a greeting. She wants to be talked to. She wants you to ask her questions, and she wants to reveal herself to you. You must speak with her night and day. The poet should not wait to greet her until the day of her departure, for it is very unlikely that he will be given her new address. On the other hand, you should not be tedious in your attentions, for there is another way to fall out of poetry's favor. This is to kill her through excess. This idea is so intuitive that one of our great writers said that too much attention stunts a plant's growth. Neither neglect nor artifice, but art.

I will not say the same of Mr. Sílvio Romero, and for a particular reason. The author of the Cantos do Fim do Século is one of the most scholarly members of the new generation. He is hardworking and capable. The readers of this Revista have no doubt accompanied with interest the criticism that Mr. Sílvio Romero has published on popular poetry in Brazil. The articles of parliamentary analysis published some months ago in the Repórter, and that were attributed to him, were not always fair, and varied in quality, but they nonetheless contained some ingenious, perceptive observations. They lacked style, and this is the great shortcoming of Mr. Sílvio Romero's writing. I do not refer to flowery verbal ornamentation, or to verbal gymnastics. Rather I refer to style, which is indispensable for a writer, and even to science. This is the style that shines forth from Renan and Spencer, and the style that Wallace ${ }^{124}$ admires in Darwin. ${ }^{125}$ Notwithstanding this shortcoming, which Mr. Romero will overcome in time,

${ }^{124}$ Alfred Russel Wallace (1823-1913): British naturalist. His theory of evolution predated Darwin.

${ }^{125}$ Charles Darwin (1809-1882): British naturalist, author of a highly influential theory of evolution by natural selection. 
and notwithstanding certain other aspects that are subject to criticism, the works I have cited are admirable for the study and dedication demonstrated by their author.

The Cantos do Fim do Século are a record of their author's dedication, but they are not the work of a poet. To put it plainly, Mr. Romero does not have a gift for poetic form. I trust that the reader does not suppose that I am referring to his rather conventional language, nor am I particularly concerned with meter. Instead I am speaking of poetic form in its true sense. A man can possess the most elevated ideas and the strongest emotions, and may bring them to life with a lively imagination. This can make for an excellent page of prose, if he knows how to write prose, or a pleasing or even great passage of poetry, if he is a poet. But what is indispensable is that the writer have command of the form in which he is going to write. The critic cannot deny that Mr. Romero has certain ideas that lend themselves to poetry, but an inability to translate these ideas into writing ultimately renders them as good as nonexistent. I believe that a good number of literary failures have at their heart this conflict between idea and form; he who formulates the idea, in his own way, believes that he has succeeded in fully transmitting it to the page, but he is mistaken. In Mr. Romero's book we see this struggle between a thought that seeks expression and a form that cannot convey this thought, or that misrepresents it or conveys it unclearly. This gives one the impression of a foreigner with only rudimentary command of our national language.

Mr. Romero belonged to the Hugoist school, which was inaugurated in the North and spread through the South some years ago. This writer attributes an importance to this movement that is not at all in keeping with reality. This said, his poetry is not identifiable as the product of this school- that is, if it is a school. Mr. Romero's poetry belongs to this school in a biographical rather than a stylistic sense. Perhaps Mr. Romero, in collecting his verses, decided to trim them of the adornments and excess ornamentation that were the vestiges of the time in which they were written. In fact, one of his compositions, "Revolução," which is included here in its 1878 version, lacks some of the truly audacious images that it possessed when I read it in 1871, in the issue of the Diário de Pernambuco dated July $23^{\text {rd }}$ of that year. Other such images no doubt remain, and can be found elsewhere in the book, though they are not so severe as to place Mr. Sílvio Romero among the disciples of Castro Alves and Mr. Tobias Barreto. 
I would be better able to demonstrate this if I had access to all of the documents necessary for the study of this poetic movement, which incidentally produced some good poetry and enthusiastic supporters.

Whatever my opinion of Mr. Romero's poems, I concede that they are undeserving of the severe criticism, much less the insulting comments that, as their author reports in a note, have been made about some of them. Mr. Romero writes: "The poet was hurt because of some of the hard truths delivered by the critic." 126 This may be the case, and for this very reason, the author should never have included this note in his book. Truly, writers who respond to literary criticism with insults give the impression of great mediocrity — or of unchecked pettiness - or of both simultaneously, and in the face of these criticisms, the talented writer, if his talent is real and accompanied by modesty, should maintain a disdainful silence: Non ragionar de lor, ma guarda, e passa. ${ }^{127}$

It is rare that writers tolerate analysis of their work, and it is rarer still that they react kindly to it. Hence the satisfaction one feels in finding such reactions among writers who are just beginning their careers. When this occurs, criticism manages to leave behind the mass of vain, petulant writers eager to declaim their verses in amphitheaters, and enters a realm in which pure love of art trumps the cheers of the crowd. Two names now come to mind-Mr. Lúcio de Mendonça and Mr. Francisco de Castro ${ }^{128}$ — poets who granted me the privilege of introducing them to the public by writing prefaces to their work. ${ }^{129} \mathrm{I}$ did not conceal from either writer, nor from the public, the faults or gaps I found in their work. And both men, the author of Névoas Matutinas and the author of Harmonias Errantes, openly and graciously accepted my criticisms. Is this not a proof of their talent?

One of these poets, Mr. Francisco de Castro, made his debut a year ago, with a book of youthful verses that in truth were often tentative, as is to be expected in a young writer. I said to Mr. Francisco de Castro: "Do not be ashamed of the

\footnotetext{
126 'Injuriavam ao poeta por causa de algumas duras verdades do crítico.'

${ }^{127}$ Machado quotes Canto III of Dante's Inferno: "non ragioniam di lor, ma guarda e passa" 'let us not talk of them, but look and pass' The English is taken from Allen Mandelbaum's translation of The Divine Comedy (New York: Alfred A. Knopf, 1995).

${ }^{128}$ Francisco de Castro (1857-1901): Medical doctor and writer, born in Salvador da Bahia.

${ }^{129}$ Machado prefaced Mendonça's Névoas Matutinas (1872) and Castro's Harmonias Errantes (1878).
} 
imperfections [in your work], nor take umbrage in seeing them exposed. Rather, be thankful... There is a promising spontaneity in your work, an individuality that comes naturally, which art will guide and time will refine." 130 I then noted that he seemed to have exhausted his store of personal poetry, and having observed other poems whose inspiration seemed more disinterested, I counseled him to write more in this vein. I told him this on August 4, 1878. A little more than a year has passed, not enough time to question if he will ever put this advice into practice. Though based on what he has already given to us in Harmonias Errantes, one may judge what Mr. Francisco de Castro can do, if he truly dedicates himself to poetry.

In this volume of two hundred pages, in which there are some weak notes, one nonetheless feels the breath of poetry, and sees poetic spontaneity and felicitous expression. At times there is also sincere feeling, as in these lovely verses from "Ao pé do berço": "God graces your cheek with a kiss, / And in dreams He appears to you. / Your heart warms / From the heat of the wing that does not enfold you. // At times, when you are sleeping, I lean / Over your crib, and I try to read the blank page / Reserved for you by destiny; / With both love and fear, / My pensive, melancholy face draws near, / Your pure, curious face. // Like a ray of light shining forth from paradise, / Your lips form an innocent smile... / Seeing you like this, ecstatic, I am happy / I take in your body's scent of flowers, /An oasis in a desert of love, / A white page in my black book."131

Fatherhood has inspired these lines. Love has inspired others, and still others are the work of an imagination that is unquiet, and that seeks to flee from reality. Perhaps he expresses this desire too strongly. Reality is fine. It is realism that is worthless. It seems evident to me that Mr. Francisco de Castro can and should look more deeply for inspiration, and should broaden his horizons. "Tiradentes,"

\footnotetext{
130 'Não se envergonhe de imperfeições, nem se vexe de as ver apontadas; agradeça-o antes... Há nos seus versos uma espontaneidade de bom agouro, uma natural singeleza, que a arte guiará melhor e a ação do tempo aperfeiçoará.'

131 'Deus perfuma-te a face com o beijo, / E em sonhos te aparece, / Quando, ao calor de uma asa que não veio / O coração te aquece. // Às vezes, quando dormes, eu me inclino / Sobre teu berço, e busco do destino / Ler a página em flor que nele existe; / De tua fronte santa e curiosa / Docemente aproximo, temerosa, / A minha fronte pensativa e triste. // Como um raio de luz do paraíso, / Teu lábio esmalta virginal sorriso... / Ao ver-te assim, extático me alegro / Bebo em teu seio o hálito das flores, / Oásis no deserto dos amores, / Página branca do meu livro negro.'
} 
"Ashaverus," and "Spartaco" are poems that show that he is capable of bringing an assertive quality to his poetry, and to good effect. Not all of the lines in these poems are above reproach, but they are lively and expressive. And when the poet speaks of heroes, as in these lovely verses, "Ye, who round time's promontory, / And, enter eternity's harbor," one can hardly recall that this is the same poet who, a few pages earlier, leaned over his child's crib. ${ }^{132}$ Poets who can write on such divergent themes have a broad and fertile field of operation before them. Mr. Francisco de Castro will no doubt abandon certain excesses with time. The best lessons are learned through one's own experience. However, I do have one reservation. Science is in Mr. Francisco de Castro's poetry like an intrusive neighbor. Indeed, he is an assiduous and fearless defender of science. Let him recall that the ancients placed these things in their proper order. They made Apollo the god of both poetry and medicine. Goethe ${ }^{133}$ wrote Faust and discovered a bone in the human skeleton, which proves that science and poetry may be reconciled to one another. The author of Harmonias Errantes has it within him to demonstrate that they are friends.

What I said to this poet in 1878, I said to the author of Névoas Matutinas in 1872. I told him plainly that the pale leaves I observed in his Spring outnumbered the green. These were my words to him, and I counseled Mr. Lúcio de Mendonça away from a premature and all-consuming melancholy. Seven years have passed. Four years ago, in 1875, he published another collection, Alvoradas. In explaining the book's title in his prologue, he states that his poems have neither the light nor the harmony of dawn. They are, rather, like a rainy early morning: disconsolate, silent, and monotonous. Let the reader take heart: one need not take refuge indoors, fearing the foul weather Mr. Lúcio de Mendonça foretells. His are the exaggerations of a poet. His morning is a clear one. It may have rained during the night, for watery tears are visible on the flowers, but the morning is clear.

A comparison between the two books works to the poet's favor. Certain hesitations and commonplaces that one notes in the first are absent from the second, though the spirit that animates them is the same. One finds in Alvoradas,

\footnotetext{
132 'Vós que dobrais do tempo o promontório, / E, barra dentro, a eternidade entrais'

${ }^{133}$ Johann Wolfgang von Goethe (1749-1832): German writer and polyglot intellectual. His Faust was published in two parts, in 1808 and 1832.
} 
as in Névoas Matutinas, both personal and political currents. Politically, Mr. Lúcio de Mendonça shares the aspirations of the new generation, which date from 1872 or even $1871 .{ }^{134}$ For evidence of this poet's talent, one may choose from among several lovely lines, such as these, from "Lenço branco": "Do you recall, Aninha, my country pearl / Now set in the city's gold, / Do you recall, oh lovely companion, / Our younger days of long ago? // Instead of this sky blue slipper, / Your little feet frolicked in rough sandals... / You were a country girl when you left me, / At the moment of departure, your white handkerchief," or the beautiful poem "Alice," which is among the best poems of this type that we have produced. But I would like to share another, less personal work. ${ }^{135}$ I would like to quote from "A família." In this poem a young man, unmarried and lost, leaves in the direction of the ocean, with the idea of taking his own life. All of a sudden, he stops, and looks through a glass window: "The room was well appointed, warm, and comfortable. / At a table, with a lamp at her side, the mother sat. / She was sewing. Farther on, a pair of children, / Smiling and gentle like hopes for the future, / Looked together at a book of pictures, / Leaning over it with their pure little heads. / In a study, its door cracked open, he could see / A man-it was the father-who, calm and serious, was writing. / Finally, an elderly woman. She was alone / Praying. She could only be the grandmother. / And in all of this there was a peace, there was comfort... / Oh! Family! Home! A calm port / In a stormy sea. Shelter, love, affection. / The young man saw it all. He turned back from his path."136

\footnotetext{
${ }^{134}$ Possible historical references for 1871 include the Lei do Ventre Livre (Law of the Free Womb), which abolished slavery for children born to enslaved women in Brazil, and the Paris Commune.

135 'Lembras-te, Aninha, pérola roceira / Hoje engastada no ouro da cidade, / Lembras-te ainda, ó bela companheira, / Dos velhos tempos da primeira idade? // Longe dessa botina azul celeste, / Folgava-te o pezinho no tamanco... / Eras roceira assim quando me deste, / Na hora de partir, teu lenço branco;'

136 'Era elegante a sala, e quente e confortada. / À mesa, junto à luz, estava a mãe sentada. / Cosia. Mais além, um casal de crianças, / Risonhas e gentis como umas esperanças, / Olhavam juntamente um livro de gravuras, / Inclinando sobre ele as cabecinhas puras. / Num gabinete, além que entreaberto se via, / Um homem —era o pai,_calmo e grave, escrevia. / Enfim uma velhinha. Estava agora só / Porque estava rezando. Era, decerto, a avó. / E em tudo aquilo havia um paz, um conforto... / Oh! a família! o lar! o bonançoso porto / No tormentoso mar. Abrigo, amor, carinho. / O moço esteve a olhar. E voltou do caminho.'
} 
The idea behind this composition could not be simpler. But here the simplicity of the idea, the poet's sober touches and the truth of his description contribute to the poem's effect, and make for nothing less than an excellent page of verse. Mr. Lúcio de Mendonça possesses the secret of artistic creation. While there is no other poem of this type in Alvoradas, there may well be in his third book. Recently he has published poems in the press of broader inspiration, and which are imbued with external reality. I have read them as they have appeared, but I have not read them closely enough to be able to analyze them in any detail. I know that these are from the second phase of Mr. Lúcio de Mendonça's poetic career, and it is in these compositions that he shows himself most closely aligned with the ideas of the new generation. The author of Alvoradas has the advantage of bringing to these subjects a refined, clear sense of form.

The poetry of Mr. Ezequiel Freire ${ }^{137}$ is not merely defined by a personal lyricism, but also has notes of humor and satire. And in this final respect we can connect him to Mr. Artur Azevedo. ${ }^{138}$ Flores do Campo, a volume of verses published in 1874, was graced by a preface written by the delicate, fine hand of D. Narcisa Amália, ${ }^{139}$ a young and beautiful poetess who some years ago piqued our interest with a book of verses, and then retreated to the turris eburnea ${ }^{140}$ of domestic life. Both Mr. Ezequiel Freire and D. Narcisa Amália are from Resende, ${ }^{141}$ and aside from this commonality, we have their poetry, which in its deepest and most heartfelt aspects is the same. Naturally, the poetess gravitates toward those compositions by Mr. Ezequiel Freire that most closely reflect her own personality, and this woman's delicacy is revealed to us in the poems that have earned her the most fervent applause. Dona Narcisa Amália gives unreserved praise to "Escravos no eito," which is set in the country, and in which Mr. Ezequiel Freire offers pious descriptions of the suffering of slaves. She does not merely applaud the poem, but subscribes to the views expressed in it. For my part, I share her praise, and I believe that the poem captures what it seeks to

${ }^{137}$ Ezequiel Freire (1850-1891): poet, prose writer and critic.

${ }^{138}$ Artur Azevedo (1855-1908): poet, prose writer, playwright and journalist. Brother of novelist Aluísio Azevedo (1857-1913).

${ }^{139}$ Narcisa Amália (1852-1924): poet, short story writer, translator, and the first Brazilian woman to work as a professional journalist.

140 'Ivory tower' in English.

${ }^{141}$ Resende is a municipality located in the south of the state (formerly province) of Rio de Janeiro. 
describe. He paints the scene in lively, raw colors, in full and energetic verses. The invective conveyed in the poem's second part would have greater impact, however, if the poet were more succinct, though in this section of the poem he conveys a real feeling of commiseration.

One finds in Mr. Ezequiel Freire's book other scenes of country life. One of the most interesting compositions in the book is simply titled "Na roça." This piece describes the poet's house, next to the barnyard, surrounded by agaves, with a thatched roof. Outside the house, a tico-tico scurries about in the straw, and the gurundi hops about in the grumichama tree. ${ }^{142}$ Nothing is missing, neither the lowing of the cattle nor the games played by the young neighborhood boys: "The cattle low in their large corral; / A group of neighborhood boys / Play Tempo-será; birds fly over / From the nearby wall. // From down the forest path, / The notes of a sad song are heard. / Oh! the heavenly smiles - of the young country girls / Oh! the love songs—-sung by a friend!"143

There is nothing missing from this scene. Or rather, there is only one thing missing, but this is everything. What is missing is a certain girl who left one day for the Court. ${ }^{144} \mathrm{~A}$ sense of utter absence completes the scene so well that it would seem to have been conjured up to give this poetic effect. And I believe that it was. The saudades that wash over us in the poem's final lines are simply too much: "Oh, you who live in the Court, / Know that I live here like a lizard. / Oh, winds that blow, tell that girl / That there are two beds in my humble room..."

Lúcia, who becomes Luciola, is another scene of country life, but one that is less successful. Here the poet narrates a simple story. There is a lively, gay note

${ }^{142}$ Tico-tico: rufous-collared sparrow (Zonotrichia capensis); gurundi: ruby-crowned tanager (Tachyphonus coronatus), also called Tiê-preto; grumichama: tree sometimes referred to as the Brazil cherry (Eugenia brasiliensis).

${ }_{143}$ ' $\mathrm{O}$ gado muge no curral extenso; / Um grupo de moleques doutra banda, / Brinca o Tempo-será; vêm vindo as aves / Do parapeito rente da varanda. // No carreador de além, que atalha a mata, / Ouvem-se notas de canção magoada. / Ai! sorrisos do céu—das roceirinhas / Ai! cantigas de amor-do camarada!'

${ }^{144}$ Machado refers to Rio de Janeiro, imperial Brazil's capital which, as the site of the royal court, was referred to as the Corte (Court).

145 'Ó gentes que morais aí na corte, / Sabei que vivo aqui como um lagarto. / Ó ventos que passais, contai à moça / Que há duas camas no meu pobre quarto...' 
in this poem that does not always manage to temper its melancholy topic. I have noted that there is a humorous vein in Mr. Ezequiel Freire's poetry. This poem's third part is full of humor that is sharpened by satirical intent. I like this final section less than the first two. The subjects it addresses are neither interesting nor always clearly expressed. This is partially explained by the poetess from Resende: "His satire, being almost always allusive, may be difficult to understand for those who do not know the poet intimately." 146 If this is the case, then the poet should abandon satire. Further, the poet's style here falls far below the bar set by the rest of the volume, which incidentally, remains imperfect. Certainly this aspect of his writing is well developed, as in "José de Arimatéia," which concerns a missing cat. But what a difference there is between this poem and "Nevoeiro"! Humor has its place, particularly in a book that at times is quite personal. But humor is best when it is spontaneous.

I do not know if Mr. Ezequiel Freire has written more verses. I would imagine that he has, and it would be lamentable if he has not. I will put aside the question of how he may yet be influenced by the spirit that seems to animate his generation. It is reasonable to suppose that the author of Flores do Campo will follow the path opened by Mr. Afonso Celso Júnior, Mr. Lúcio de Mendonça, and Mr. Teófilo Dias, whose first flowers have already bloomed.

If we cannot find traces of the new tendency in Mr. Ezequiel Freire, it is more difficult still to find them in Mr. Artur Azevedo, who is a purely satirical poet. I have read three volumes by this writer: Dia de Finados, A Rua do Ouvidor, and Sonetos. I reveal nothing new about this writer in stating that the style he displays in these books is incorrect, and that his versification lacks the necessary polish and is not properly matched to the material. In reading these pages, one feels the poet's deliberate carelessness, one senses improvisation, one perceives an amateur's lack of refinement. Apart from this criticism, which reveals a great deal about his work, another occurs to me, and of equal gravity. It is not merely his poems' overall design that is flawed. What is more, the colors he utilizes are excessively bold, and the topics he addresses are not always poetic. I use the term "poetic" bearing in mind that he is a satirical poet. But whether one writes satirical or epic poetry, one's subject matter must satisfy certain artistic

146 'A sátira, sendo quase sempre alusiva, faz-se obscura para os que não gozam a intimidade do poeta.' 
conditions. The poem "Dia de finados," for example, describes certain episodes that must be grounded in some degree of reality. It would have been inopportune for the poet to invent these whole cloth. Even so, the criticism stands: not all of these episodes merit inclusion in the poem, and indeed, taken together they ruin the poem's overall effect by compromising its verisimilitude. It can be said that a visit to one of our cemeteries on a day in which a deceased person is remembered makes for a largely unenlightening spectacle. Would one eat in the cemetery on such a day? The meal the poet describes for us is a true workingman's feast, from which nothing is lacking, not even drunkenness. The scene becomes all the more incomprehensible when we reflect that sadness is not absent from this scene. The poet makes this point clearly, writing the following about one of the banqueters: "She is tempted by a shrimp; / She takes it in her hand, and a tear falls on it." 147 The widow who loudly reprimands a slave, the creditor who is about to collect a debt, a lover's rendezvous, the taunts, the laughter: does all this not seem exaggerated? But even if we assume that all of this is taken wholly from life, it still is not entirely acceptable material for narrative poetry. In the end, the poet raises himself out of the ditch that runs across the plain and presents us with some affecting verses: he laments partial charity, painless pain, and tears that do not burn.

"Rua do Ouvidor" and his Sonetos naturally do not give the same impression as "Dia de finados," because their satire is less exaggerated. The first of these works is a review of our great street, ${ }^{148}$ a lighthearted review in which $\mathrm{Mr}$. Azevedo's good and bad qualities announce themselves clearly. This satire's principal defect is its length. Poems of this sort should not greatly exceed Tolentino's "Passeio" in length. ${ }^{149}$ The majority of Mr. A. Azevedo's poetic work is comprised of sonnets. Not all of them are perfect, and in some cases, as in "Metamorfose," the subject of the sonnet exceeds the writer's capacity to treat it poetically. But there are other sonnets whose guiding idea is elegantly conceived and which are written in a more refined style. This is the case of a sonnet dedicated to a scolding neighbor. This sonnet's conclusion will give the

\footnotetext{
147 'Um camarão a atrai; / Vai a comê-lo, e nele a lágrima lhe cai'

${ }^{148}$ The Rua do Ouvidor was the center of elegant life in the Rio de Janeiro of the Brazilian belle époque. Machado de Assis' fiction routinely referenced this street.

${ }^{149}$ Nicolau Tolentino de Almeida (1740-1811): Eighteenth-century Portuguese satirical poet.
} 
reader a sense of the quality of the poet's verses when he gives them the proper polish: 'You, who are the beast in a woman's form, / Oh! You bark, bark and bark, and bark again and bark... / But before you bark let me leave here forever. ${ }^{150}$

Mr. Múcio Teixeira has already published a great deal: three volumes of poetry, with a fourth volume, Novos Ideais, announced for publication. ${ }^{151}$ In the title of this new book, and in certain poems that I have recently seen published in newspapers, one can see the nature of Mr. Múcio Teixeira's relationship with the better part of this new army of poets, and I have nothing more to add on this score. In his other works, principally in his Sombras e Clarões, we can see this poet's good and bad qualities. It seems that thus far, Mr. Múcio Teixeira has been influenced primarily by the so-called Hugoist school. "O trono e a igreja," "Gutenberg," "Posterioridade," and other compositions give us a thorough understanding of this poet, who has sought after poetic effects through purely mechanical means. Once again we have the condor, that condor that having soared through so many poems some twelve years ago, ended up falling to the earth, where it was scooped up and stuffed. ${ }^{152}$ We have the epic, we have Prometheus, giants, towers of Babel — an entire vocabulary designed to occupy a space that might otherwise be filled with ideas. Mr. Múcio Teixeira was carried away by the current, as were so many others. We need not censure him. It is enough that he ultimately resisted, and that his new book will be of another sort.

Mr. Múcio Teixeira may be the most easily inspired of the new poets. One senses that verses flow from him readily and in abundance. His verses are of good quality. They should be employed discretely, but I do not believe that Mr. Múcio Teixeira can resist himself. There is movement in these verses, but there are also excesses. The poet falls short at times, lacking clarity and propriety. When the poet is truly overtaken by emotion, these defects disappear or at least diminish. But true emotion is rare in Mr. Múcio Teixeira's verses. It is not impossible that

150 'Tu, que és o cão tinhoso em forma de senhora, / Oh! ralha, ralha e ralha, e ralha mais e ralha. . . Mas deixa-me primeiro ir para sempre embora.' In Portuguese, "cão tinhoso" is a name attributed to the Devil.

${ }^{151}$ Múcio Teixeira (1857-1926): poet, playwright, biographer, translator, and critic, born in Porto Alegre.

${ }^{152}$ Here Machado makes a barbed reference to condoreirismo, a late manifestation of Romanticism in Brazilian poetry, which took hold in the 1860s. 
the author of Sombras e Clarões prefers subjects that require a certain grandiloquence. In other poems he utilizes less elevated language and a milder tone, and I believe that his muse is much better served by these poems. The others fall far short of the mark. If my space were not so constrained, I would present, as examples, the differing results achieved by Mr. Múcio Teixeira in these two types of poem. I would demonstrate the superiority of "Noite de verão," "Desalento," and "Eu" over "Voz profética" and "Fantasmas do porvir." There may be something of the artificial in "Desalento," but here his poetry comes more naturally, his expression is fit to the subject: here he is another poet. Then what of the artificial is there in this poem? At times Mr. Múcio Teixeira manages to express sincerity in his poems. The following verses, which are incidentally a bit low in tone, and which conclude the poet's dedication of Sombras e Clarões, seem to be sincere: "If I did not yet distrust everything in this world / I-who had drunk deeply of life's bitter cup, / Crying in silence, and laughing at the crowd... // I found in you the blessings and affection / Of a child in his home, or a bird in its nest... / Friend of my parents, I kiss your hand!"153

Mr. Múcio Teixeira appears to write these sorts of lines, in which expression corresponds to the idea, and in which the idea is clearly conceived, without much effort. I am certain that his good qualities will easily prevail in his new book, and I also believe that he will make better use of his ease of expression, which is one of his talents, and will fulfill the expectations that his first compositions created, and with good reason. If there is one piece of advice he might take from a critic it would be to turn his back on the past.

III

I am confident that the impression the reader receives of the new generation from this assessment is neither entirely positive nor entirely negative, but both positive and negative, which for this generation is as it should be. He has seen that this generation has within its ranks men of talent, even great talent. The movement lacks unity, but has confidence and style to spare. And if their ideas sometimes

153 'Se ainda não descri de tudo neste mundo / Eu—que o cálix do fel sorvi até o fundo, / Chorando no silêncio, e rindo à multidão; // É que encontrei em vós as bênçãos e os carinhos / Que a infância tem no lar, e as aves têm nos ninhos. . Amigo de meus pais! eu beijo a vossa mão.' 
tend toward the unexceptional and the vulgar, and other times tend singlemindedly toward fantasy, these ideas nonetheless reveal an effort to engage in something other than a direct continuation of the past. This intention alone is a promise of future success. To revile the past and to idolize it: these amount to the same vice. This is the vice of those who are ignorant of the ties that bind them to the past, and who believe that the age of human glory begins with them. This is likewise the vice of those who imagine that at some point along its path, the human spirit cast off its wings and stepped into the mire. Youth should be forgiven this first view, because at their age lack of reflection is taken as a sign of courage, and a bit of injustice toward the past is necessary in order to gain the future. And in fact the young poets do not reject what came before them, but are merely searching for something different.

It is impossible to determine the size or durability of this poetic movement. External circumstances may help move it forward and define it, though it may also meet its end or transform into something else. Regardless, I believe that some of these poets will emerge from the movement and continue the work that they have begun. A great number of them are sure to become involved in more concrete pursuits. Among these some will be compelled by age to cease being poets: with their muse extinguished, their poetry will come to an end. Some will take this well, and for others, it may be a cause of hidden resentment. Those who fall silent will fail to understand that language has not abandoned them. Of those who are now young men, those who continue in their work will learn what sort and what degree of effort this requires. For them, moral and literary problems will be joined together.

The new generation is drawn to scientific writers. There is among them not one poet worthy of the name who has not conversed, at least a bit, with the modern naturalists and philosophers. They should, however, guard against the defect of pedantry. In general the youth, particularly in periods of scientific and literary renewal, are preoccupied with nothing more than demonstrating to others that these others have ignored certain things. Hence names recently committed to memory and misunderstood terms are quickly put down on paper, and the more difficult the names and words, the better. I say to the young men that true learning does not serve as ornamentation, but is consumed as a form of nutrition, and that the way to demonstrate that one understands a scientific process is not to speak of it incessantly, but to apply it correctly. The examples to follow in this are the 
luminaries of science. Young men, reread your Spencer and your Darwin. Avoid also this defect: the sectarian spirit, which is proper to established generations and petrified institutions. The sectarian spirit moves necessarily from the hateful to the ridiculous. It was not for a wide and far-seeing generation that the following, truly elegant line was written: "Nul n'aura de l'esprit, hors nous et nos amis." 154

Finally, I would say that this generation has the future in its hands, provided that its enthusiasm does not wane. It may yet acquire what it lacks, and discard that which diminishes its luster. It may simply affirm itself and continue along its path. If its work does not yet have a clear, definitive expression, it may yet achieve this in time. The competent among them will achieve it. A writer from beyond our shores, Sainte-Beuve, ${ }^{155}$ said one day that while a talent may bury himself in a bad system, if he is true and original he will quickly free himself and achieve poetic truth. These words, spoken by a critic who was also a poet, are now repeated by one who labored for a period of years in both criticism and poetry. While his labor was neither significant nor fruitful, it was pursued with dedication and sincerity. He will always have friendly advice and render due praise to those who come after him.

\footnotetext{
154 'Except our friends and us, none shall have wit.' Line from Molière's Les Femmes savantes (1672).

${ }^{155}$ Charles Augustin Sainte-Beuve (1804-1869): French critic and literary historian.
} 